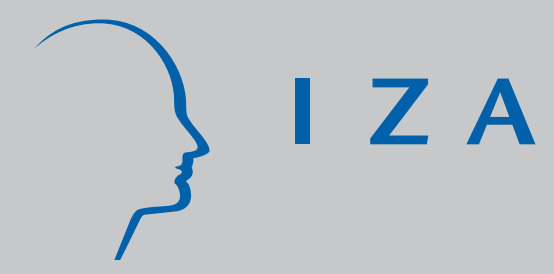

IZA DP No. 1395

The Economic Causes and Consequences of Canadian Citizenship

Don J. DeVoretz

Sergiy Pivnenko

November 2004 


\title{
The Economic Causes and Consequences of Canadian Citizenship
}

\author{
Don J. DeVoretz \\ RIIM, Simon Fraser University \\ and IZA Bonn \\ Sergiy Pivnenko \\ RIIM, Simon Fraser University \\ Discussion Paper No. 1395 \\ November 2004
}

\author{
IZA \\ P.O. Box 7240 \\ 53072 Bonn \\ Germany \\ Phone: +49-228-3894-0 \\ Fax: +49-228-3894-180 \\ Email: iza@iza.org
}

\begin{abstract}
Any opinions expressed here are those of the author(s) and not those of the institute. Research disseminated by IZA may include views on policy, but the institute itself takes no institutional policy positions.

The Institute for the Study of Labor (IZA) in Bonn is a local and virtual international research center and a place of communication between science, politics and business. IZA is an independent nonprofit company supported by Deutsche Post World Net. The center is associated with the University of Bonn and offers a stimulating research environment through its research networks, research support, and visitors and doctoral programs. IZA engages in (i) original and internationally competitive research in all fields of labor economics, (ii) development of policy concepts, and (iii) dissemination of research results and concepts to the interested public.
\end{abstract}

IZA Discussion Papers often represent preliminary work and are circulated to encourage discussion. Citation of such a paper should account for its provisional character. A revised version may be available directly from the author. 
IZA Discussion Paper No. 1395

November 2004

\section{ABSTRACT}

\section{The Economic Causes and Consequences of Canadian Citizenship*}

Immigrants ascend to citizenship at differential rates in Canada. Why is this so? This paper investigates the economic costs and benefits derived from citizenship to rationalize the differential rates of citizenship ascension. Canadian earnings evidence confirms the sizable economic benefits of citizenship. A decomposition analysis attributes this benefit to selfselection, namely only the more productive immigrants become Canadian citizens.

JEL Classification: F22, J61, J68

Keywords: immigration, citizenship, Canada

Corresponding author:

Sergiy Pivnenko

Centre of Excellence: Immigration

Simon Fraser University

8888 University Drive

Burnaby, BC, V5A 1 S6

Canada

Email: spivnenk@sfu.ca

${ }^{*}$ This is a substantially revised version of the Economics of Canadian Citizenship which will appear in the Willy Brandt Series of Working Papers (www.bit.mah.se/MUEP). 


\section{Introduction}

The long-term goal of Canadian immigration policy is to insure that the majority of its foreign-born arrivals become citizens. To this end the current Canadian ministry of immigration is charged to perform both immigrant selection and citizenship functions. Moreover, the majority of foreign-born permanent immigrants to Canada are entitled to apply for citizenship after a three-year period of residency. According to the 1996 Census of Canada, $74.6 \%$ of Canada's foreign-born were citizens.

In addition the majority of Canada's post-1986 immigrant flows emanate from China and India, and, after 5 years in residence, these immigrants ascend to citizenship at an annual rate of between 15 to $20 \%$ of the resident stock per year ${ }^{i}$. The process is nearly complete after the $25^{\text {th }}$ year in residence as the stock of residents from China and India have largely acquired citizenship. Just the opposite picture emerges for immigrants from the traditional source countries of Western Europe and the United States. Here significant immigrant ascension to citizenship only appears after 25 years or more in residence.

Rates of ascension vary even amongst immigrants from Western Europe. For example, more than $68 \%$ of Polish immigrants to Canada had acquired citizenship, whereas only 24 per cent of Dutch immigrants had become citizens. Finally, over $17 \%$ of all foreign-born residents reported dual citizenship in 1996, with the largest source countries appearing in Western Europe and the United States.

These stylized facts belie the degree of controversy that has arisen in Canada with respect to the economic implications of citizenship acquisition. In 2003 the Canadian Supreme Court upheld the citizenship requirement for an array of federal government jobs, and ruled against an immigrant class action suit to recover damages from alleged discrimination. ${ }^{\text {ii }}$ The plaintiffs argued that both job and earnings discrimination arose under this requirement, since immigrants without citizenship were unable to practice their profession and enjoy the relatively high earnings from a federal position. Another issue has arisen as a byproduct of linking citizenship with the growth in return migration of erstwhile Canadian immigrants. It has been observed that over $25 \%$ of the post-1986 Chinese immigrants to Canada had returned to Hong-Kong or China by 2004, most with Canadian citizenship (DeVoretz and Ma 2002). Canadian policymakers have made ambivalent pronouncements over the economic impact of this phenomenon. Some 
policymakers consider the returning erstwhile Canadian immigrants a Canadian asset which will increase trade and investment. Other observers are less sanguine and feel that these Chinese-Canadian emigrants are potential future liabilities, especially if they return to retire, thus putting economic pressure on the social system. iii In addition, Canada's membership in NAFTA now affords all Canadian citizens, including immigrants who recently ascended to citizenship, the right to work in the United States in selected highly skilled jobs. This exacerbates the concerns over Canada's brain drain (DeVoretz and Iturralde 2001). iv $^{\text {in }}$

In sum, both Canadian immigrants and Canadian policymakers face a new set of economic issues which arise from the process and the outcomes of immigrant ascension to citizenship. Beyond these issues, a series of fundamental questions however need to be addressed, including:

- What are the individual determinants that affect immigrants' decision to ascend to citizenship at various stages in their lifetime?

- Do immigrants economically gain in either the public or private labour markets from their ascension to citizenship?

- $\quad$ From an economic perspective, what is the optimal waiting period before Canada should allow ascension to citizenship?

In order to answer these questions we propose to model:

- The affect of economic (income, occupation), social (marital status, household size, children, etc.), political (dual citizenship) and demographic (age, years in Canada) variables on the immigrants' decision to ascend to citizenship;

- The economic impact of citizenship on the occupational distribution and earnings of immigrants.

\section{Literature}

The economic literature on citizenship primarily consists of two separate views. One view attempts to rationalize an immigrant's decision to acquire citizenship and the other view investigates the economic consequences of such decision. The evidence on the determinants of acquiring citizenship remains highly controversial largely due to the specifics of the populations studied and the varying nature of the data used. While some 
authors (Kelley and McAllister, 1982; Portes and Mozo, 1985) insist on the importance of economic variables, such as education, occupation and income, others (Bernard, 1936; Barkan and Khokhlov, 1980, Portes and Curtis, 1987) put forward cultural assimilation and demographic characteristics as major determinants of immigrant's naturalization decision. With the aid of 1980 U.S. Census microdata Yang (1994) applied a cost-benefit framework to investigate the effects of individual characteristics and socio-economic conditions of home and host countries on immigrant's citizenship decision. His findings indicate that cultural integration plays a more important role than economic integration in the naturalization process. Age at immigration, marital status and presence of children were among the demographic factors that increase the odds of becoming a citizen. While the home country level of development proved to be a significant predictor of immigrant's naturalization decision, the availability of dual citizenship did not obtain the expected effect.

The other stream of studies ignores the economic rationale for becoming a citizen and addresses only the possible economic impacts of immigrant citizenship. For example, Bratsberg et al. (2002) using a youth panel data set find that immigrant ascension to citizenship alters the immigrants' occupational distribution and raises their earnings in the United States labour market. Moreover, they argue that these effects are greater for immigrants from less developed countries. Other economic studies of labour market outcomes of citizenship are more limited in scope since they mostly incorporate the citizenship affect as an addendum to a larger study. Pivnenko and DeVoretz (2004) found a strong citizenship affect on Ukrainian immigrant earnings in Canada. Mata (1999) reports no evidence on the economic impact of Canadian citizenship on immigrant earnings after conducting a principal components analysis with 1996 Canadian data. In reviewing the economic outcomes of Chinese-Canadian citizens who returned to HongKong, DeVoretz and Zhang (2004) found that returnees earned higher incomes in HongKong than any other resident group. In the Swedish case, Bevelander (2000) reports that the log odds of obtaining employment improved for those immigrants who obtained Swedish citizenship in $1990 .^{\mathrm{v}}$

In sum, we conclude from this brief literature survey that no comprehensive study of both citizenship ascension and its economic impact exists. 


\section{Stylized Facts}

Table 1 reports some socio-economic data for the 1996 Canadian foreign-born population by citizenship status. We focus on those variables which most frequently appear in a human capital model of earnings. The age of foreign-born non-citizens is much lower, with over $46 \%$ of this group under the age of 36 , while foreign-born citizens comprise only $33 \%$ or less of this relatively young age group (Figure 2).

Table 1: Stylized Facts of Canadian Citizen and non-Citizen Populations: employed immigrants 18-65 years old

\begin{tabular}{|c|c|c|c|c|c|c|c|c|}
\hline & \multicolumn{2}{|c|}{ All immigrants } & \multicolumn{2}{|c|}{ Citizens } & \multicolumn{2}{|c|}{ Non-citizens (All) } & \multicolumn{2}{|c|}{ Non-citizens (5yrs+) } \\
\hline & Frequency & Percent & Frequency & Percent & \begin{tabular}{|l|} 
Frequency \\
\end{tabular} & Percent & Frequency & Percent \\
\hline \multicolumn{9}{|l|}{ Age } \\
\hline $17<$ age $<26$ & 6307 & 9.49 & 4033 & 8.02 & 2274 & 14.04 & 786 & 9.65 \\
\hline $25<$ age $<36$ & 15833 & 23.82 & 10587 & 21.06 & 5246 & 32.39 & 1975 & 24.26 \\
\hline $35<$ age $<46$ & 18668 & 28.08 & 14124 & 28.09 & 4544 & 28.06 & 2336 & 28.69 \\
\hline $45<$ age $<56$ & 17505 & 26.33 & 14541 & 28.92 & 2964 & 18.30 & 2148 & 26.38 \\
\hline $55<$ age $<66$ & 8158 & 12.27 & 6991 & 13.91 & 1167 & 7.21 & 897 & 11.02 \\
\hline \multicolumn{9}{|l|}{ Tenure in Canada } \\
\hline $0-5$ years & 10864 & 16.34 & 2811 & 5.59 & 8053 & 49.73 & 0 & 0 \\
\hline $6-10$ years & 9813 & 14.76 & 7753 & 15.42 & 2060 & 12.72 & 2060 & 25.30 \\
\hline $11-15$ years & 6213 & 9.35 & 5190 & 10.32 & 1023 & 6.32 & 1023 & 12.56 \\
\hline $16-20$ years & 8014 & 12.06 & 6805 & 13.54 & 1209 & 7.47 & 1209 & 14.85 \\
\hline $21-25$ years & 10015 & 15.07 & 8521 & 16.95 & 1494 & 9.23 & 1494 & 18.35 \\
\hline $26-30$ years & 8864 & 13.34 & 7645 & 15.21 & 1219 & 7.53 & 1219 & 14.97 \\
\hline $31-35$ years & 3977 & 5.98 & 3464 & 6.89 & 513 & 3.17 & 513 & 6.30 \\
\hline $36-40$ years & 4512 & 6.79 & 4096 & 8.15 & 416 & 2.57 & 416 & 5.11 \\
\hline $41-45$ years & 3103 & 4.67 & 2939 & 5.85 & 164 & 1.01 & 164 & 2.01 \\
\hline $46+$ years & 1096 & 1.65 & 1052 & 2.09 & 44 & 0.27 & 44 & 0.54 \\
\hline \multicolumn{9}{|l|}{ Highest degree } \\
\hline $\mathrm{H} /$ School or less & 30087 & 45.26 & 22013 & 43.78 & 8074 & 49.85 & 4241 & 52.09 \\
\hline Diploma & 21552 & 32.42 & 16904 & 33.62 & 4648 & 28.70 & 2494 & 30.63 \\
\hline Bachelor & 8905 & 13.40 & 6852 & 13.63 & 2053 & 12.68 & 837 & 10.28 \\
\hline Above bachelor & 4953 & 7.45 & 3777 & 7.51 & 1176 & 7.26 & 456 & 5.60 \\
\hline Ph.D. & 974 & 1.47 & 730 & 1.45 & 244 & 1.51 & 114 & 1.40 \\
\hline \multicolumn{9}{|l|}{ Occupation } \\
\hline Unskilled & 32909 & 49.51 & 23569 & 46.88 & 9340 & 57.67 & 4250 & 52.20 \\
\hline Skilled & 13749 & 20.68 & 10747 & 21.38 & 3002 & 18.54 & 1776 & 21.81 \\
\hline Professional & 19813 & 29.81 & 15960 & 31.74 & 3853 & 23.79 & 2116 & 25.99 \\
\hline \multicolumn{9}{|l|}{ Weeks worked } \\
\hline $0-25$ & 10297 & 15.49 & 6696 & 13.32 & 3601 & 22.24 & 1212 & 14.89 \\
\hline $26-40$ & 8498 & 12.78 & 5899 & 11.73 & 2599 & 16.05 & 1115 & 13.69 \\
\hline \multirow[t]{2}{*}{$41-52$} & 47676 & 71.72 & 37681 & 74.95 & 9995 & 61.72 & 5815 & 71.42 \\
\hline & \multicolumn{2}{|c|}{ Mean } & \multicolumn{2}{|c|}{ Mean } & \multicolumn{2}{|c|}{ Mean } & \multicolumn{2}{|c|}{ Mean } \\
\hline Wage earnings & \multicolumn{2}{|c|}{$\$ 27,909$} & \multicolumn{2}{|c|}{$\$ 29,931$} & \multicolumn{2}{|c|}{$\$ 21,632$} & \multicolumn{2}{|c|}{$\$ 27,063$} \\
\hline Total income & \multicolumn{2}{|c|}{$\$ 30,873$} & \multicolumn{2}{|c|}{$\$ 33,003$} & \multicolumn{2}{|c|}{$\$ 24,262$} & \multicolumn{2}{|c|}{$\$ 29,977$} \\
\hline
\end{tabular}

Source: Authors' tabulations from 1996 Census of Canada 
Figure 1: Age distributions of immigrant groups by citizenship status

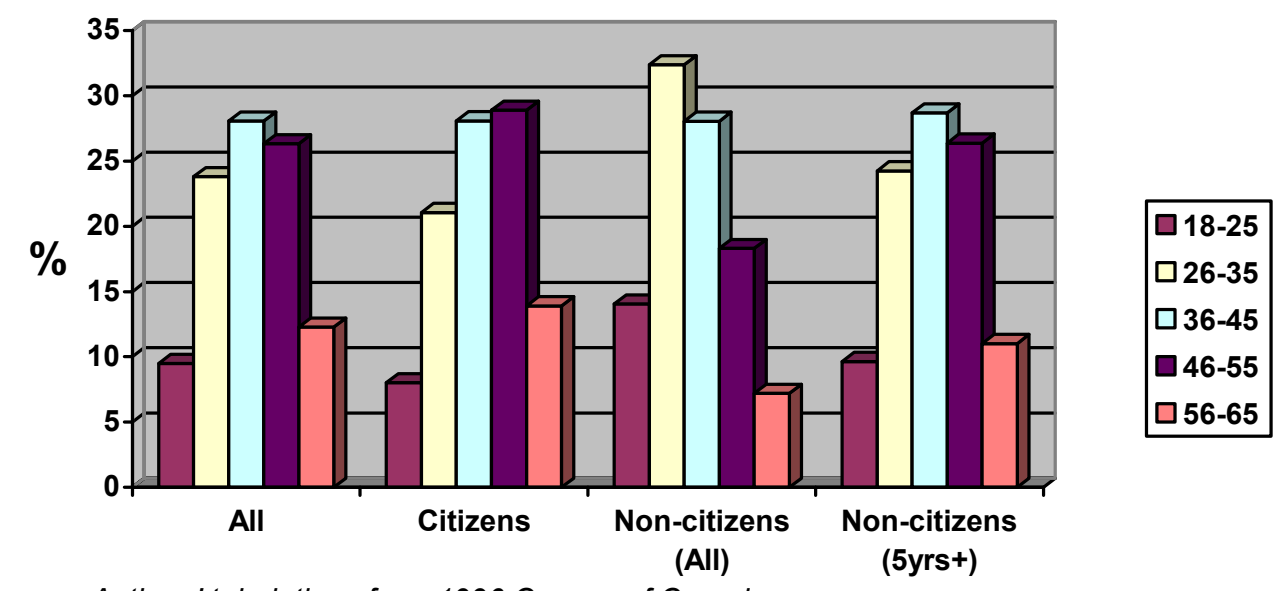

Source: Authors' tabulations from 1996 Census of Canada

This finding may be spurious since age is correlated with years in Canada (tenure). Given that an immigrant must wait approximately three years to qualify for citizenship, we would expect that the citizen (non-citizen) population would be older (younger). In fact, the distribution by tenure in Canada reported in Table 1 reflects this observation since $50 \%$ of non-citizens have been in Canada less than 5 years.

Non-citizens also report less education with $50 \%$ or more having a high school or less qualification; thus these non-citizens are also over-represented in the unskilled category, with $58 \%$.

The labour force participation of non-citizens is also skewed with only $61 \%$ participating full time in the Canadian labour force as compared to $75 \%$ for immigrants who became citizens.

If the observed age, low educational qualifications, limited skills and weeks worked are combined for non-citizens, then you would expect that the wage earnings and total income of non-citizens would be considerably lower than that of citizens who have a greater human capital endowment. This proves to be true since non-citizens earn approximately 8,000 dollars, or $25 \%$, less than citizens.

In sum, this brief overview indicates that citizenship status is correlated with human capital endowment and earnings performance for Canadian immigrants. 


\section{Theory: Costs and Benefits of Ascending to Canadian Citizenship}

The economic problem that immigrants face is to choose a state: citizenship or noncitizenship, which maximizes their income net of citizenship ascension cost given their human capital stock. Figure 3 imbeds the citizenship decision inside a more general model of moving and staying (DeVoretz et al. 2002). Each stage of this journey involves a decision to move or stay, and this decision is, in turn, is conditioned by possible ascension to citizenship.

Figure 2: Decision Tree: Stay-Leave

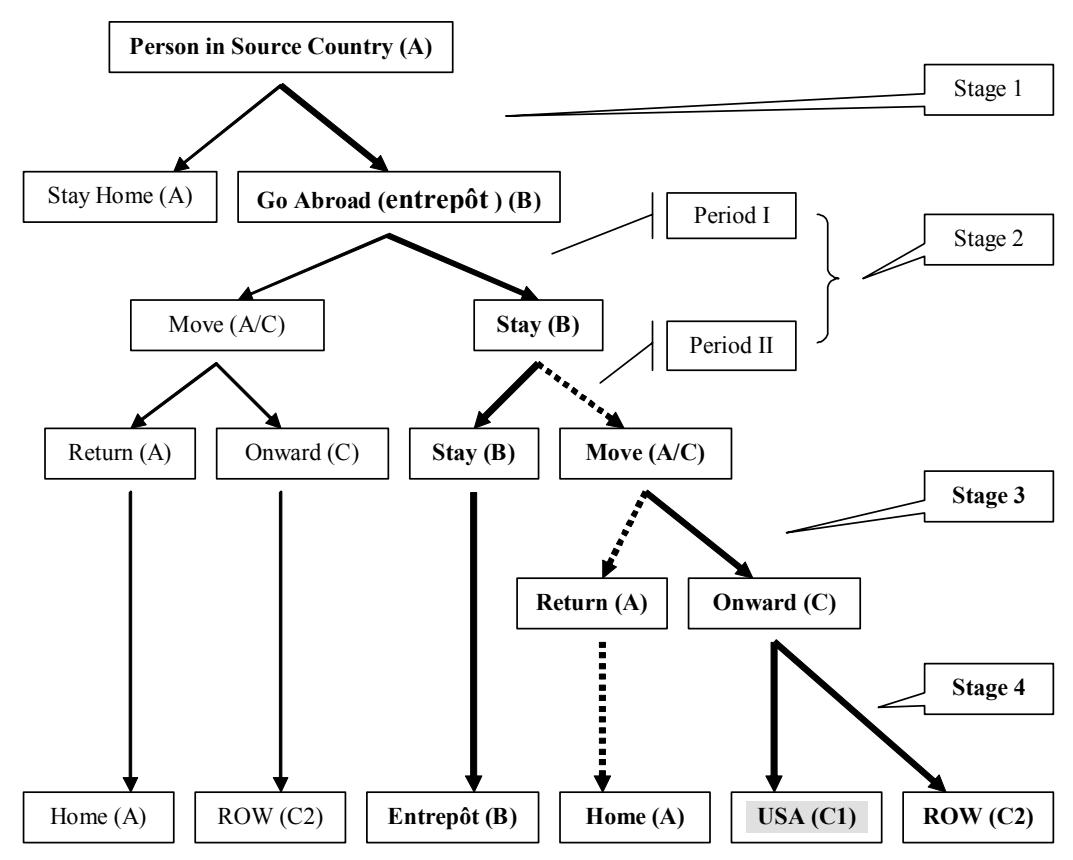

For purposes of illustration, we will follow only one branch of this decision tree to simplify the argument. To focus on the citizenship decision, we only follow the bold path. In stage 1 , the immigrant resides in country A and decides to move to country B. This movement was presumably motivated by the prospect of higher earnings and the 
opportunity to acquire subsidized human capital in stage 2 (period 1) and a public good (a passport) in stage 2 (period 2), if citizenship is obtained in country B in stage 2 (period 2).

Both the acquisition of subsidized human capital and the prospects of receiving a free public good (a passport) now increase the probability that this immigrant will ascend to citizenship in Stage 2, if the expected earnings stream in country B net of costs exceeds the option of returning home. The latter result is an outcome of an assumption that country A (e.g. China) does not recognize dual citizenship, and would prohibit return migration as a citizen of country B. ${ }^{\mathrm{vi}}$ But will the newly ascended citizen of country B stay in country B in stage 3 and beyond? Only if the net income gains from staying as a citizen in country B exceed the income gains from a citizen of country B moving to the USA or the rest of the world (ROW). In sum, there will be no immigrant ascension to citizenship in country B if the home country (A) income rewards exceed the other 3 options when no dual citizenship is permitted by country A. In fact, the optimization problem for the immigrant is to choose a mobility path which maximizes the net income given the human capital endowment, and transaction costs of movement and obtaining citizenship.

In the absence of mutual recognition of dual citizenship by both Canada and the sending country, the major cost of ascending to Canadian citizenship is the loss of home country citizenship. This implies,

- $\quad$ no access to the home country labour market;

- $\quad$ the possible loss of the right to hold land, or higher taxes to pay on land;

- $\quad$ no entitlement to public services, such as subsidized education for children;

- $\quad$ curtailing of social insurance benefits.

Application fees and any foregone income arising from continued residence in Canada to fulfill citizenship requirements add to the costs of ascending to citizenship.

On the other hand, the benefits from Canadian citizenship include:

- $\quad$ access to the federal government labour market;

- $\quad$ potential access to the US labour market (NAFTA TN visa);

- $\quad$ any wage premium paid by private Canadian employers to Canadian citizens;

- $\quad$ a Canadian passport and visa waivers which lead to greater mobility. 
If this model holds, then rates of ascension to citizenship are a positive function of the immigrant's age, years in Canada, skilled occupational status, home ownership, marital status and presence of children, since each of these factors affects the costs and benefits of ascending to citizenship. In addition, the greater the income earned by the immigrant prior to citizenship in the destination country, the greater the probability of ascending to citizenship.

We acknowledge that other factors outside this human capital framework affect the immigrant's decision. Figure 3 points to further conditioning factors in the citizenship acquisition decision beyond the human capital arguments cited above.

Figure 3: Proportion of naturalized citizens among immigrants from high income countries (USA, Germany, Italy, Netherlands) and low income countries (China and India)

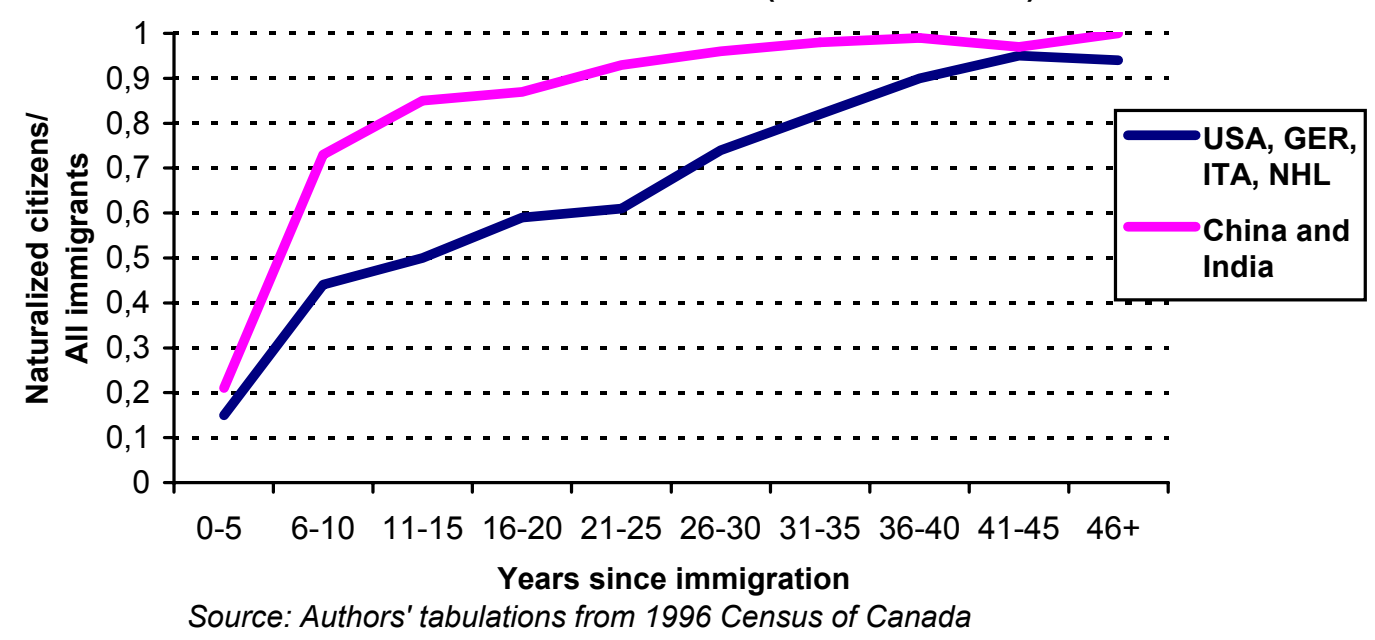

Figure 3 illustrates the cumulative process of immigrant ascension to citizenship for two vintages of immigrants. As noted earlier, immigrants from China and India largely complete their citizenship acquisition between the $6^{\text {th }}$ and $11^{\text {th }}$ year (after five years in residence), when $80 \%$ of the Chinese and Indian stock of immigrants have become Canadian citizens.

The older vintage of European and United States immigrants experience a mild spurt in citizenship acquisition in the first five years of eligibility, from $10 \%$ to $40 \%$, but do not approach the Chinese or Indian rates of citizenship acquisition until after 45 years of residence in Canada. 
Why is there such a gap across countries of origin and vintages of immigrants? Several forces appear to be acting on these vintages of immigrants to affect their probability of citizenship acquisition, and any modeling exercise must recognize these forces. First, the foregone income in the home country conditions the speed of ascension. In the absence of dual citizenship recognition, the immigrant faces a low opportunity cost by foregoing the opportunity of return migration after the move to Canada then citizenship acquisition is earlier and faster.

Next, the ease and desire for family reunification will affect the immigrant's decision to acquire citizenship. If Chinese and Indian immigrants show a greater propensity to sponsor family members than the older European vintage of immigrants (Akbar, 1995), return migration by Chinese and Indian immigrants will be less likely.

In addition, differential benefits of acquiring Canadian citizenship accrue to the two groups depicted in Figure 3. Acquisition of Canadian citizenship by Chinese and Indian nationals affords a potential increase in labour mobility since these groups can enter the United States labour market with a TN or NAFTA visa. Of course, United States and Western European passports would yield entry to their holders into NAFTA or EU labor markets respectively, without the necessity of acquiring Canadian citizenship and a Canadian passport.

In sum, human capital characteristics plus immigrant source country characteristics (level of development, dual citizenship recognition and portability of home citizenship) should be incorporated in an economic model of citizenship acquisition.

\section{Results: Citizenship Acquisition}

First we report our regression results for our model of citizenship ascension for all of Canada's major immigrant sending countries. ${ }^{\text {vii }}$ Since we also feel that citizenship may vary by gender, we further disaggregate our results by gender. ${ }^{\text {viii }}$ For male immigrants (Table 2-A) most of the life-cycle variables obtain the predicted sign and are significant. The effect of the income variable (LNWDIF) that measures the predicted logarithmic differences of citizen versus non-citizens wages is relatively small and negative. ${ }^{\mathrm{ix}}$ Home ownership (HOWN) and years since immigration (YSM), strongly influence the log odds of ascending to citizenship. Although being legally married generally decreases the 
likelihood of ascension to citizenship, presence of young children partially offsets this effect.

Table 2-A. Model of probability of acquiring Canadian Citizenship (1996): Male Immigrants from all countries

\begin{tabular}{|l|r|r|r|r|r|}
\hline & \multicolumn{1}{|c|}{ Coeff. } & b/St.Er. & P $[|Z|>Z]$ & Mean of X & Elasticity \\
\hline Constant & -0.28786 & -3.848 & 0.0001 & & \\
\hline AGE & 0.009143 & 4.611 & 0.0000 & 43.38212 & 0.073352 \\
\hline LMARRIED & -0.21998 & -4.577 & 0.0000 & 0.787355 & -0.03077 \\
LMAR_CHL & 0.137247 & 3.518 & 0.0004 & 0.384171 & 0.009654 \\
YSM10_15 & 1.547801 & 27.643 & 0.0000 & 0.116314 & 0.022689 \\
YSM16_21 & 1.55922 & 31.981 & 0.0000 & 0.185319 & 0.039244 \\
YSM22_27 & 1.555827 & 29.948 & 0.0000 & 0.171376 & 0.035681 \\
YSM28_33 & 1.745231 & 24.711 & 0.0000 & 0.092566 & 0.018857 \\
YSM34_38 & 1.974547 & 23.603 & 0.0000 & 0.078847 & 0.016839 \\
YSM39PL & 2.676078 & 23.385 & 0.0000 & 0.071056 & 0.017156 \\
HOWNER & 0.365816 & 10.389 & 0.0000 & 0.700902 & 0.049639 \\
LWAGEDIF & -0.08871 & -3.498 & 0.0005 & 0.050131 & -0.00082 \\
\hline Number of observations & 26824 & & \multicolumn{2}{|c|}{ Log likelihood function } & -12237.8 \\
Chi Squared & \multicolumn{3}{|c|}{3892.167} & Restricted log likelihood & -14183.88 \\
\hline
\end{tabular}

Notes: Logistic regression: dependent variable CTZN

Source: Authors' calculations from 1996 Census of Canada

Table 2-B indicates that there is one difference in immigrant ascension by gender as the effect of the predicted wage difference becomes strongly positive. The remaining variables for the female equation obtain similar signs and significance as those reported for males in Table 2-A. 
Table 2-B. Model of probability of acquiring Canadian Citizenship (1996):

Female Immigrants from all countries

\begin{tabular}{|l|r|r|r|r|r|}
\hline & Coeff. & b/St.Er. & P $[|Z|>Z]$ & Mean of X & Elasticity \\
\hline Constant & -0.3512 & -3.893 & 0.0001 & & \\
\hline AGE & 0.007152 & 3.153 & 0.0016 & 42.23825 & 0.057184 \\
\hline LMARRIED & -0.15737 & -3.236 & 0.0012 & 0.720462 & -0.021 \\
LMAR_CHL & 0.216705 & 4.614 & 0.0000 & 0.323964 & 0.012978 \\
YSM10_15 & 1.523287 & 24.017 & 0.0000 & 0.124322 & 0.024864 \\
YSM16_21 & 1.652548 & 29.777 & 0.0000 & 0.200687 & 0.046244 \\
YSM22_27 & 1.541088 & 26.78 & 0.0000 & 0.181235 & 0.038874 \\
YSM28_33 & 1.583654 & 20.211 & 0.0000 & 0.089946 & 0.017727 \\
YSM34_38 & 2.11472 & 19.489 & 0.0000 & 0.060992 & 0.013454 \\
YSM39PL & 2.738332 & 18.842 & 0.0000 & 0.057858 & 0.01409 \\
HOWNER & 0.308999 & 7.609 & 0.0000 & 0.704045 & 0.042809 \\
LWAGEDIF & 0.680476 & 22.545 & 0.0000 & 0.145651 & 0.018762 \\
\hline Number of observations & 20101 & & Log likelihood function & -9190.686 \\
Chi Squared & 3271.442 & \multicolumn{5}{|c|}{ Restricted log likelihood } & -10826.41 \\
\hline
\end{tabular}

Notes: Logistic regression: dependent variable CTZN

Source: Authors' calculations from 1996 Census of Canada

We now turn to the effect of the level of development in the immigrant source country on ascension to Canadian citizenship in Tables 3-A and 3-B. The results for immigrants from non-OECD countries and OECD countries are vastly different. ${ }^{\mathrm{x}}$ In the OECD case, the wage earnings difference between immigrants with and without citizenship status, home ownership and years in Canada are significant and correctly signed. The household composition effects (age, marital status, presence of children) are either insignificant, or obtain the incorrect sign and do not condition either male or female OECD immigrant citizenship ascension as predicted. ${ }^{\mathrm{xi}}$ 
Table 3-A. LOGIT Model of probability of acquiring Canadian Citizenship (1996): Female and Male Immigrants from OECD countries

\begin{tabular}{|l|r|r|r|r|r|}
\hline & \multicolumn{1}{|c|}{ Coeff. } & \multicolumn{1}{l|}{ b/St.Er. } & P $[|\mathrm{Z}|>\mathrm{Z}]$ & Mean of X & Elasticity \\
\hline Constant & -0.37047 & -3.632 & 0.0003 & & \\
\hline AGE & -0.00426 & -1.795 & 0.0726 & 45.35844 & -0.03645 \\
\hline LMARRIED & -0.00695 & -0.126 & 0.8999 & 0.77241 & -0.00101 \\
LMAR_CHL & -0.05259 & -1.042 & 0.2974 & 0.292479 & -0.00292 \\
YSM10_15 & 0.990141 & 12.189 & 0.0000 & 0.069625 & 0.009848 \\
YSM16_21 & 1.423024 & 20.776 & 0.0000 & 0.170989 & 0.03416 \\
YSM22_27 & 1.647506 & 24.468 & 0.0000 & 0.229282 & 0.054277 \\
YSM28_33 & 2.086652 & 27.065 & 0.0000 & 0.170369 & 0.044023 \\
YSM34_38 & 2.617567 & 28.933 & 0.0000 & 0.138516 & 0.038708 \\
YSM39PL & 3.2373 & 29.251 & 0.0000 & 0.131244 & 0.040221 \\
HOWNER & 0.184497 & 3.772 & 0.0002 & 0.792367 & 0.028519 \\
LWAGEDIF & 0.680207 & 20.654 & 0.0000 & 0.093558 & 0.01201 \\
\hline Number of observations & 17738 & & Log likelihood function & -8198.826 \\
Chi Squared & 2516.746 & & Restricted log likelihood & -9457.198 \\
\hline
\end{tabular}

Notes: Logistic regression: dependent variable CTZN

Source: Authors' calculations from 1996 Census of Canada

The non-OECD results reported in reported in Table 3-B are in sharp contrast to the OECD results. First, the wage variable is insignificant and obtains an incorrect sign. In addition, household composition and time-related variables (age and years in Canada) have strong positive effects on the immigrant's decision to ascend to citizenship.

Table 3-B. LOGIT Model of probability of acquiring Canadian Citizenship (1996): Female and Male Immigrants from NON-OECD countries

\begin{tabular}{|l|r|r|r|r|r|}
\hline & \multicolumn{1}{|c|}{ Coeff. } & b/St.Er. & P $[|Z|>Z]$ & Mean of X & Elasticity \\
\hline Constant & -0.42993 & -3.718 & 0.0002 & & \\
\hline AGE & 0.01001 & 3.377 & 0.0007 & 41.40097 & 0.067753 \\
\hline LMARRIED & -0.33643 & -4.727 & 0.0000 & 0.79576 & -0.04092 \\
LMAR_CHL & 0.316553 & 5.382 & 0.0000 & 0.429349 & 0.021903 \\
YSM10_15 & 2.040359 & 25.372 & 0.0000 & 0.173307 & 0.037875 \\
YSM16_21 & 2.455972 & 25.405 & 0.0000 & 0.179411 & 0.04451 \\
YSM22_27 & 3.007945 & 19.825 & 0.0000 & 0.1154 & 0.028025 \\
YSM28_33 & 3.426967 & 10.589 & 0.0000 & 0.036377 & 0.007571 \\
YSM34_38 & 2.913817 & 8.912 & 0.0000 & 0.022272 & 0.004296 \\
YSM39PL & 3.928956 & 7.742 & 0.0000 & 0.024086 & 0.004971 \\
HOWNER & 0.544134 & 10.8 & 0.0000 & 0.659738 & 0.062255 \\
LWAGEDIF & -0.04853 & -1.294 & 0.1956 & 0.096509 & -0.00077 \\
\hline Number of observations & 12123 & \multicolumn{5}{|c|}{ Log likelihood function } & -5166.489 \\
Chi squared & 3268.895 & \multicolumn{5}{|c|}{ Restricted log likelihood } & -6800.937 \\
\hline
\end{tabular}

Notes: Logistic regression: dependent variable CTZN

Source: Authors' calculations from 1996 Census of Canada 
Given the stylized facts reported in Figure 3, there also appears to be a distinct behavioral break between those groups who ascend to citizenship when first eligible (between 4 to 6 years) and a second group who ascends to citizenship after 10 years of residence in Canada. Tables 3-C and 3-D report the regression results for those immigrants who chose to ascend to Canadian citizenship when it was first available to them, i.e., between the $4^{\text {th }}$ and $6^{\text {th }}$ year of residence in Canada, and after 10 years in residence.

Table 3-C. LOGIT Model of probability of acquiring Canadian Citizenship (1996): All Immigrants with 4-6 years in residence

\begin{tabular}{|c|c|c|c|c|c|}
\hline & Coeff & b/st.Er. & $P[|Z|>z]$ & Mean of $X$ & Elasticity \\
\hline Constant & 0.778829 & 5.169 & 0.0000 & & \\
\hline $\mathrm{AGE}$ & 0.015654 & 3.905 & 0.0001 & 37.63465 & 0.137149 \\
\hline LMARRIED & -0.28276 & -3.106 & 0.0019 & 0.75988 & -0.04804 \\
\hline LMAR CHL & 0.096897 & 1.31 & 0.1901 & 0.486577 & 0.010968 \\
\hline HOWNER & -0.02994 & -0.478 & 0.6326 & 0.529598 & -0.00369 \\
\hline LWAGEDIF & 0.293225 & 6.128 & 0.0000 & 0.028012 & 0.001912 \\
\hline \multicolumn{3}{|c|}{$\begin{array}{l}\text { Number of observations } \\
\text { Chi squared }\end{array}$} & \multicolumn{2}{|c|}{$\begin{array}{l}\text { Log likelihood function } \\
\text { Restricted log likelihood }\end{array}$} & $\begin{array}{l}-3242.971 \\
-3271.861\end{array}$ \\
\hline
\end{tabular}

Notes: Logistic regression: dependent variable CTZN

Source: Authors' calculations from 1996 Census of Canada

Table 3-D. LOGIT Model of probability of acquiring Canadian Citizenship (1996): All Immigrants with 10 years or more in residence

\begin{tabular}{|c|c|c|c|c|c|}
\hline & Coeff & b/st.Er. & $P[|Z|>Z]$ & Mean of $X$ & Elasticity \\
\hline Constant & 1.656238 & 18.732 & 0.0000 & & \\
\hline $\mathrm{AGE}$ & -0.00174 & -0.869 & 0.3848 & 45.13002 & -0.00934 \\
\hline LMARRIED & -0.00172 & -0.037 & 0.9705 & 0.762193 & -0.00016 \\
\hline LMAR_CHL & -0.0113 & -0.265 & 0.7910 & 0.318576 & -0.00043 \\
\hline YSM16 21 & 0.100895 & 2.058 & 0.0395 & 0.268285 & 0.003165 \\
\hline YSM $22 \_27$ & 0.053706 & 1.06 & 0.2890 & 0.245494 & 0.001553 \\
\hline YSM28_33 & 0.181662 & 2.93 & 0.0034 & 0.127842 & 0.002625 \\
\hline YSM34_38 & 0.572407 & 7.705 & 0.0000 & 0.099538 & 0.0057 \\
\hline YSM39PL & 1.227357 & 12.76 & 0.0000 & 0.091435 & 0.009223 \\
\hline HOWNER & 0.192599 & 4.737 & 0.0000 & 0.790466 & 0.018909 \\
\hline LWAGEDIF & 0.430332 & 16.651 & 0.0000 & 0.10274 & 0.005261 \\
\hline \multicolumn{3}{|c|}{$\begin{array}{ll}\text { Number of observations } & 33565 \\
\text { Chi squared } & 62284\end{array}$} & \multicolumn{2}{|c|}{$\begin{array}{l}\text { Log likelihood function } \\
\text { Restricted log likelihoo }\end{array}$} & $\begin{array}{l}-12436.41 \\
-12747.84\end{array}$ \\
\hline
\end{tabular}

Notes: Logistic regression: dependent variable CTZN

Source: Authors' calculations from 1996 Census of Canada 
For the immigrants with 4 to 6 years in residence, all the reported variables except home ownership (HOWN) obtain significance and follow the model's predicted signs. For the immigrants who ascended to citizenship after 10 years of residence in Canada, the significance levels of the variables change (table 3-D). The socio-demographic variables of age, marital status and presence of children are either no longer significant, or obtain the incorrect sign. However, the wage coefficient increases in magnitude and significance along with the most of the years-in-Canada variables.

In sum, the proposed socio-economic model of immigrant ascension rationalizes the decision process for both OECD and non-OECD immigrants in different dimensions with the wage differences variable proving relevant in both cases. In addition, the model best describes the process of immigrant ascension for those with less than six years in Canada.

\section{Economic Impact: Occupational Shift}

Given the literature reviewed and the arguments contained in our theory section, two major citizenship effects should appear in the labour market. First, the occupational distribution of citizens should change to increase the number of foreign-born TNprofessional and government occupations after citizenship.

Next, controlling for all other human capital arguments, citizenship acquisition should increase the earnings for all immigrants, since they should face less labour market discrimination owing to perceived cultural differences. ${ }^{\text {ii }}$

Moreover, the earnings effect from citizenship should be greater for those immigrants with professional qualifications, since their labour market has become larger given possible entry into the United States and employment by the Canadian federal government. In fact, most foreign-born Canadian citizens in 64 occupations can immediately apply for a TN or NAFTA visa to work in the United States after obtaining a bone fide job offer.

Finally, the citizenship effect should differ by source country, with a greater effect being generated for foreign-born citizens from non-English-speaking countries. The rationale for this argument is found in Figure 2: prior to citizenship acquisition, 
subsidized English language training is made available to non-English-speaking immigrants to allow them to qualify as citizens. Thus, citizenship acquisition signals to the Canadian employer that a minimum standard of English (or French, if relevant) has been obtained.

Figures 4 and 5 illustrate the citizenship effect on the occupational distributions of males and females respectively. The three classifications of occupational distributions for the foreign-born reflect different stages in the tree diagram (Figure 2). Upon arrival in Canada immigrants must declare what their intended occupation is before entering the labour market. This intention is based on an immigrant officer's assessment of the candidate's educational qualifications prior to admission to Canada. The intended occupation of the resident foreign-born stock was strongly biased toward the professions (occupation 5), while the actual experience after arrival is strongly weighted to the lowskilled (1) or clerical (2) occupations. There is a perverse shift in the actual occupational structure for males toward clerical, and away from skilled, when they become citizens (Actual_C).

Figure 4: Intended and actual occupations of male citizen (C) and noncitizen (NC) immigrants in Canada
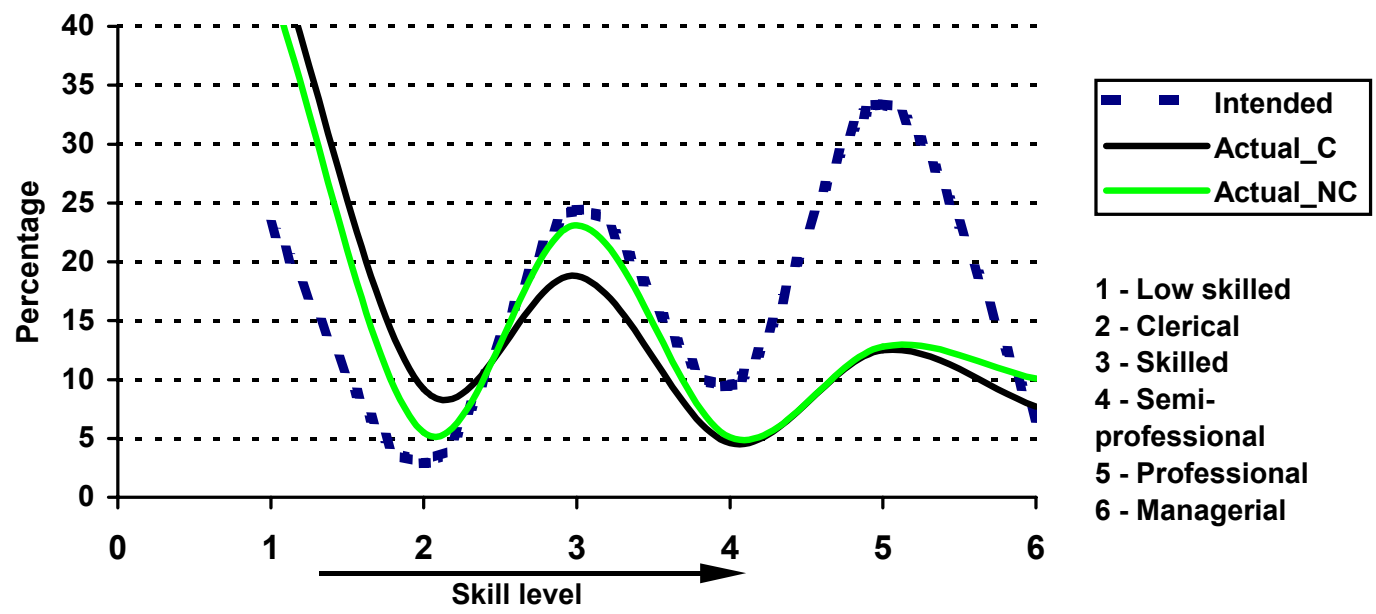

1 - Low skilled

2 - Clerical

3 - Skilled

4 - Semiprofessional 5 - Professional 6 - Managerial

Source: Authors' tabulations from IMDB and 1996 Census of Canada 
Figure 5: Intended and actual occupations of female citizen (C) and noncitizen (NC) immigrants in Canada

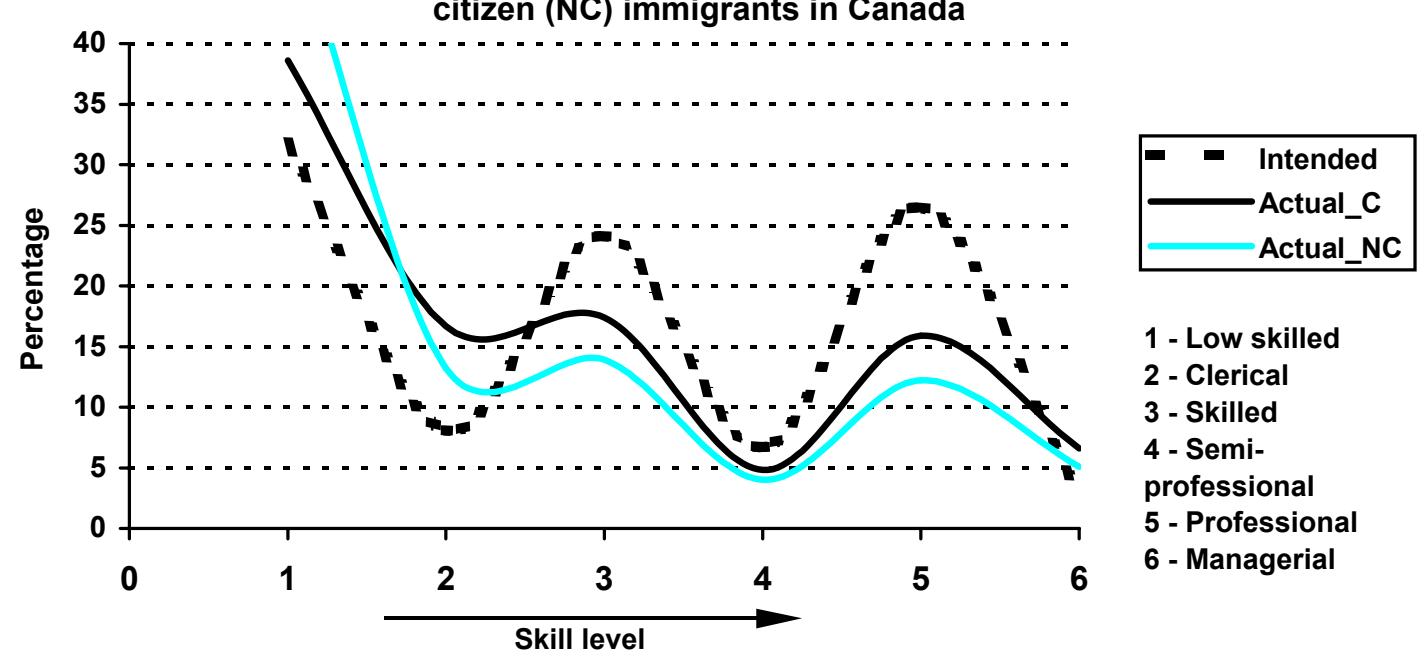

Source: Authors' tabulations from IMDB and 1996 Census of

For the female foreign-born residents in Canada (Figure 5), the distributional shifts across the three states are as predicted. The intended occupations are strongly professional upon arrival, and then the actual distribution collapses toward the lowskilled categories after arrival. When female immigrants gain citizenship, there is a restoration in the occupational distribution as it shifts back to mimic the intended occupation with a greater professional content.

In sum, we observe in Figures 4 and 5 a large shift between intended and actual occupations after arrival, and some restoration of the occupational gap for females after citizenship is obtained. This restoration does not occur for foreign-born males. This perverse result could arise since many other factors are not controlled for in this diagram between the time period of entry (intended occupation) and 1996 (actual occupation). ${ }^{\text {xii }}$

\section{Economic Impact: Earnings Shift}

Even in the absence of a meaningful occupational shift (males), an earnings effect can potentially be observed. Tables 4 and 5 report the results for two alternative human capital models to explain foreign-born earnings by gender and citizenship.

Table 4. Citizenship Effect on immigrant earnings: all foreign-born Source: Authors' calculations from 1996 Census of Canada 


\begin{tabular}{|c|c|c|c|c|c|c|}
\hline & \multicolumn{3}{|c|}{ Males } & \multicolumn{3}{|c|}{ Females } \\
\hline Variable & Coefficient & b/St.Er. & $\mathrm{P}[|\mathrm{Z}|>\mathrm{Z}]$ & Coefficient & b/St.Er. & $\mathrm{P}[|\mathrm{Z}|>\mathrm{Z}]$ \\
\hline Constant & 5.440613 & 75.025 & 0.0000 & 5.770422 & 72.099 & 0.0000 \\
\hline AGE & 0.046198 & 14.491 & 0.0000 & 0.036376 & 10.139 & 0.0000 \\
\hline AGESQ & -0.00047 & -13.29 & 0.0000 & -0.00038 & -9.106 & 0.0000 \\
\hline YSM10_15 & 0.193395 & 14.26 & 0.0000 & 0.130508 & 8.936 & 0.0000 \\
\hline YSM16_21 & 0.24101 & 19.628 & 0.0000 & 0.209656 & 15.882 & 0.0000 \\
\hline YSM22_27 & 0.304905 & 23.28 & 0.0000 & 0.231712 & 16.335 & 0.0000 \\
\hline YSM28_33 & 0.351102 & 21.891 & 0.0000 & 0.254191 & 14.42 & 0.0000 \\
\hline YSM34_38 & 0.349524 & 20.037 & 0.0000 & 0.21877 & 10.597 & 0.0000 \\
\hline YSM39PL & 0.356012 & 19.233 & 0.0000 & 0.242942 & 11.279 & 0.0000 \\
\hline LMARRIED & 0.145254 & 14.754 & 0.0000 & -0.00455 & -0.482 & 0.6301 \\
\hline CITIZ & 0.000819 & 0.077 & 0.9386 & -0.06369 & -5.205 & 0.0000 \\
\hline HLN & 0.166116 & 19.091 & 0.0000 & 0.106157 & 11.07 & 0.0000 \\
\hline DIPL & 0.143876 & 16.111 & 0.0000 & 0.116147 & 11.625 & 0.0000 \\
\hline BACH & 0.248062 & 19.623 & 0.0000 & 0.260374 & 19.345 & 0.0000 \\
\hline BACHPL & 0.352734 & 23.061 & 0.0000 & 0.369064 & 20.56 & 0.0000 \\
\hline PHD & 0.530059 & 20.808 & 0.0000 & 0.63576 & 13.504 & 0.0000 \\
\hline MAN_CTZ & 0.295307 & 20.441 & 0.0000 & 0.406621 & 19.992 & 0.0000 \\
\hline PROF_CTZ & 0.18726 & 15.602 & 0.0000 & 0.420093 & 29.579 & 0.0000 \\
\hline SUPR_CTZ & 0.166139 & 8.39 & 0.0000 & 0.258732 & 8.711 & 0.0000 \\
\hline ADM_CTZ & -0.03783 & -2.301 & 0.0214 & 0.225714 & 18.853 & 0.0000 \\
\hline LNWEEKS & 0.843172 & 91.107 & 0.0000 & 0.784096 & 79.464 & 0.0000 \\
\hline $\begin{array}{l}\text { Adjusted } \\
\text { R-squared } \\
\text { Model test } \\
\text { F[20,26803](prob) }\end{array}$ & $\begin{array}{l}0.408103 \\
925.70(.0000)\end{array}$ & & & $\begin{array}{l}0.40754 \\
692.31(.0000)\end{array}$ & & \\
\hline
\end{tabular}

Table 5: Citizenship Effect on all foreign-born earnings (Full Model) Source: Authors' calculations from 1996 Census of Canada

\begin{tabular}{|l|r|r|r|r|r|r|}
\hline & \multicolumn{3}{|c|}{ Males } & \multicolumn{3}{|c|}{ Females } \\
\hline Variable & \multicolumn{1}{|c|}{ Coefficient } & \multicolumn{1}{l|}{ /St.Er. } & P $[|Z|>$ z $]$ & \multicolumn{1}{c|}{ Coefficient } & b/St.Er. & P $[|Z|>$ z $]$ \\
\hline Constant & 5.463977 & 74.971 & 0.0000 & 5.741575 & 71.092 & 0.0000 \\
AGE & 0.046384 & 14.467 & 0.0000 & 0.037195 & 10.249 & 0.0000 \\
AGESQ & -0.00048 & -13.429 & 0.0000 & -0.0004 & -9.46 & 0.0000 \\
YSM10_15 & 0.216394 & 15.94 & 0.0000 & 0.148208 & 10.073 & 0.0000 \\
YSM16_21 & 0.27662 & 22.741 & 0.0000 & 0.241713 & 18.338 & 0.0000 \\
YSM22_27 & 0.345033 & 26.646 & 0.0000 & 0.271631 & 19.263 & 0.0000 \\
YSM28_33 & 0.393432 & 24.699 & 0.0000 & 0.295576 & 16.785 & 0.0000 \\
YSM34_38 & 0.394874 & 22.769 & 0.0000 & 0.26679 & 12.891 & 0.0000 \\
YSM39PL & 0.405865 & 22.005 & 0.0000 & 0.301128 & 13.931 & 0.0000 \\
LMARRIED & 0.136582 & 13.814 & 0.0000 & -0.01549 & -1.624 & 0.1043 \\
CITIZ & -0.00743 & -0.673 & 0.5006 & 0.04136 & 3.405 & 0.0007 \\
DIPL & 0.170976 & 19.277 & 0.0000 & 0.164073 & 16.587 & 0.0000 \\
BACH & 0.286964 & 23.243 & 0.0000 & 0.330135 & 24.962 & 0.0000 \\
BACHPL & 0.404377 & 27.14 & 0.0000 & 0.452651 & 25.585 & 0.0000 \\
PHD & 0.596354 & 23.695 & 0.0000 & 0.735393 & 15.521 & 0.0000
\end{tabular}




\begin{tabular}{|l|r|r|r|r|r|r|} 
HLN_CTZ & 0.061308 & 5.406 & 0.0000 & -0.09184 & -6.489 & 0.0000 \\
HL_CZ_MN & 0.331891 & 19.97 & 0.0000 & 0.432879 & 17.972 & 0.0000 \\
HL_CZ_PR & 0.159652 & 11.379 & 0.0000 & 0.397041 & 23.306 & 0.0000 \\
HL_CZ_SP & 0.176435 & 7.247 & 0.0000 & 0.278735 & 7.62 & 0.0000 \\
HL_CZ_AD & -0.04234 & -2.086 & 0.0370 & 0.229609 & 14.976 & 0.0000 \\
LNWEEKS & 0.852735 & 91.75 & 0.0000 & 0.796896 & 79.974 & 0.0000 \\
\hline Adjusted & \multicolumn{5}{|l|}{} \\
R-squared & 0.40121 & & 0.39348 & \\
Model test & & & & \\
F[20,26803](prob) & $899.60(.0000)$ & & & \\
\hline
\end{tabular}

Table 4 reports our preliminary earnings functions with a citizenship dummy variable $(\mathrm{CTZN})$ and a variable that interacts citizenship with occupational status. The standard human capital variables, age, age squared and years in Canada, all obtain the expected signs under a human capital earnings model. In this preliminary model, the citizenship variable (CTZ) is small for both the male and female earnings models, it however obtains the incorrect sign in the female group and is insignificant in the male case. For males and females the interaction variables for occupation and citizenship status are all statistically significant and in most cases obtain a positive sign. The exception is the coefficient on male administrative-citizenship variable, which is small and negative.

We augment our initial model by further interacting citizenship with a language dummy thus explicitly recognizing the importance of citizenship as a possible signal of language competency.

Table 5 reports the results for our language-augmented citizenship-earnings model. The citizenship variable (CTZN) has a relatively small effect on earnings, and is insignificant for males. In addition, the coefficient on language ability interacted with citizenship indicates a small but statistically significant effect on wage earnings for both groups, and obtains a negative sign in the female case. However, the interaction of first language ability and occupational status (managers, professionals and administrators) with citizenship results in a strong positive interaction which boasts male and female foreign-born citizen earnings. Again, the male administrative-citizenship variable is the exception.

Appendix $\mathrm{C}$ reports the earnings regression results for the two entry cohorts of pre1980 and post-1981 movers by gender. These two immigrant vintages were chosen to reflect the impact of the 1978 Immigration Act, which dramatically changed the 
immigrant entry gates and refined the points system. The main implication of these changes was to reconfigure the immigrant source countries from Europe and the United States to Asia and Africa. ${ }^{\text {xiv }}$ In addition, human capital characteristics became the major entry criteria for economically-assessed immigrants after 1981.

One important difference appears across the cohorts with respect to the citizenship effect on earnings. In the pre-1980 period the citizenship effect is significantly negative for males and females, while it is significantly positive after 1981. The remaining parameters in these earnings equations were stable between the two cohorts, suggesting that only the labour market's response to citizenship changed between these two periods.

\section{Economic Impact: Age Earnings Simulations ${ }^{\mathrm{xv}}$}

To illustrate the importance of the citizenship effect we produce below a series of country-specific age-earnings simulations with and without the detected citizenship effect.

Figures 6 and 7 illustrate the citizenship effect on earnings for pairs (British and Chinese, and United States and Indian) of old and new vintages of Canadian immigrants.

Figure 6. Age-earnings profiles for the Canadian Born (CB), British Immigrants Canadian citizens (BritIm_C) and non-citizens of Canada (BritIm_NC), Chinese Immigrants Canadian citizens (Chinlm_C) and non-citizens of Canada (Chinlm_NC)

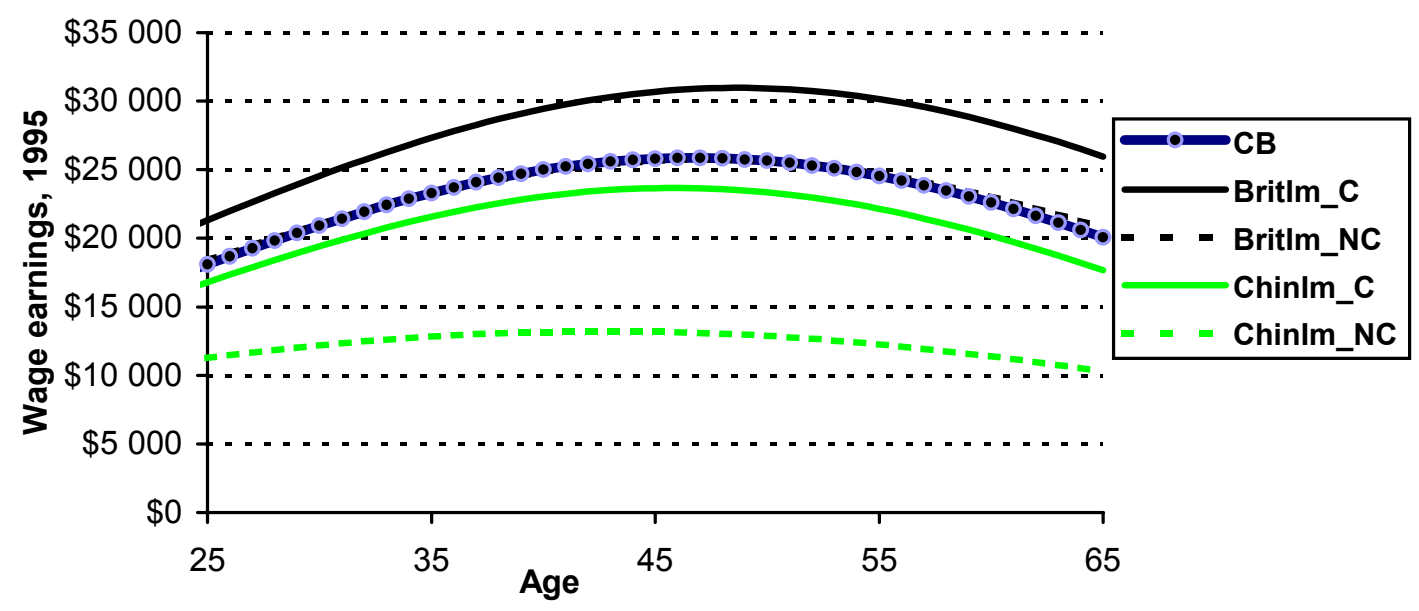

Source: Authors' calculations from 1996 Census of Canada 


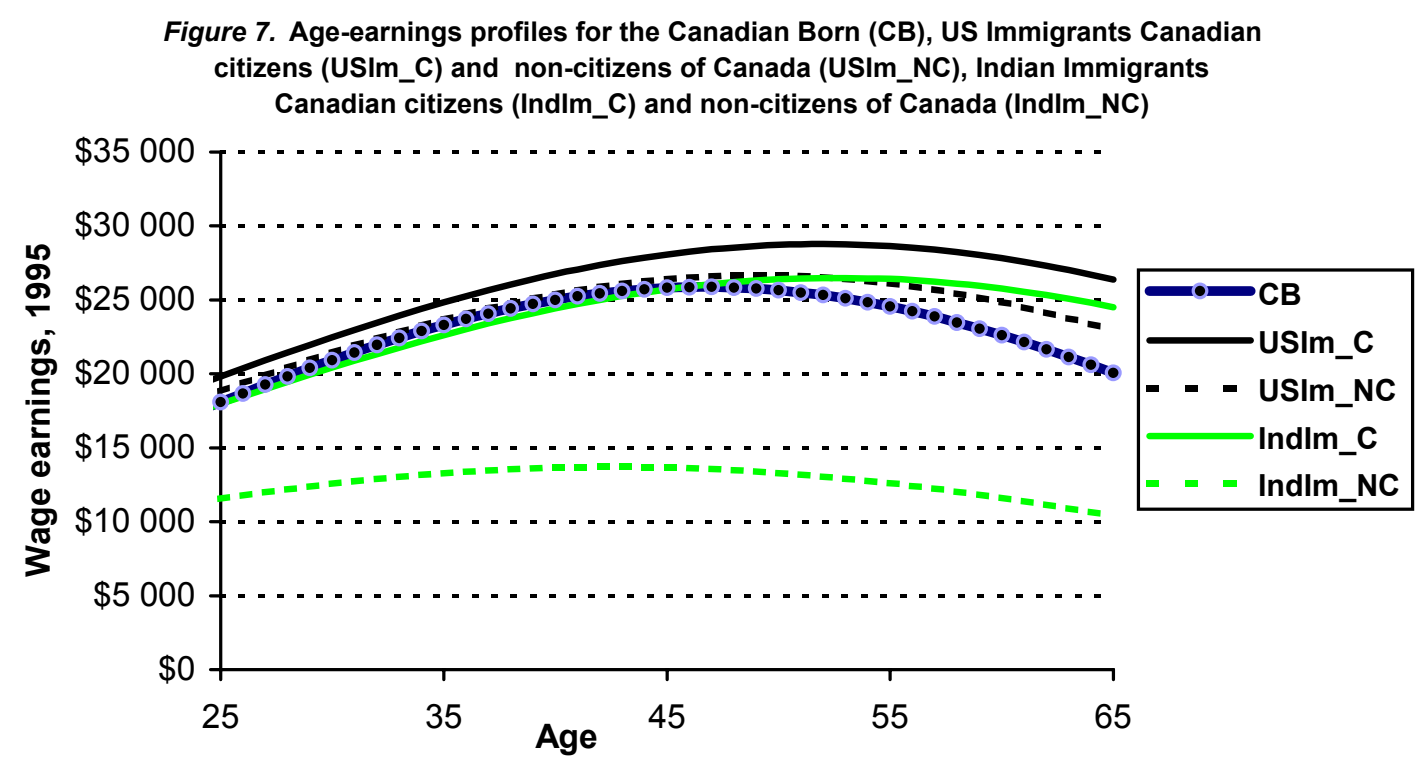

Source: Authors' calculations from 1996 Census of Canada

The citizenship effects for both the Chinese and the British are positive. However, the citizenship effect on Chinese earnings is larger. The Canadian-born age earnings functions are now reported as a reference point (CB), and further highlight the citizenship effect on earnings. For a Chinese immigrant who experiences a substantial earnings disadvantage upon arrival, becoming a citizen augments his/her earnings such as to nearly equal that of the Canadian-born. The citizenship effect on British immigrant earnings is sufficient to make these immigrants "overachievers". In other words, with citizenship British immigrants do not suffer an initial earnings disadvantage, but rather experience a continuous earnings advantage.

Figure 7 portrays a similar effect when we pair the earnings performance for the United States and Indian immigrants. Citizenship status grants United States immigrants a slight lifetime earnings premium relative to the Canadian-born. There is once again a substantial boast in the earnings of Indian immigrants from citizenship acquisition, such that Indians now overtake the earnings of the Canadian-born at age 45.

Figures B-1 through B-3 in Appendix B report a similar pattern of citizenship effects on earnings for older-vintage German and Italian immigrants and the newer Ukrainian arrivals. In all these cases, citizenship status causes immigrants earnings to 
overtake the Canadian-born norm, with the largest effect occurring for the more recent Ukrainian arrivals.

In sum, under these age-earnings simulations the citizenship effect on earnings for the reviewed countries was substantial, and in every case except the Chinese, citizenship allowed the respective immigrants to outperform the earnings of the Canadian-born.

\section{Economic Impact: Decomposition of Wage Differentials Between Naturalized and Native-born Canadians}

As suggested earlier, ascension to Canadian citizenship not only provides immigrants with access to an expanded labour market, but also rewards the newly naturalized citizen with a wage premium, as shown in Figures 6 and 7. But are these equalized earnings a consequence of non-discriminatory treatment due to citizenship or a result of the fact that newly ascended citizens have a greater stock of human capital? Given that immigrants are either singly or doubly selected, the average immigrant may have a greater human capital endowment than the average native-born Canadian. Then, after acquiring Canadian citizenship, do these better-educated and more experienced immigrants actually earn more than their native-born counterparts? If so, why? In order to answer these questions we employ the Binder-Oaxaca decomposition methodology. The basic idea underlying this method is that differences in wages between two population groups (citizens and non-citizens) can be explained by the differences in their productive characteristics, and by the differences in the OLS (Ordinary Least Squares) regression coefficients, which in turn represent returns to those characteristics.

We now turn to estimating the sources of earnings differences between naturalized and native-born Canadians. Using the pooled wage structure as a benchmark ("nondiscriminatory" structure) we obtain the decomposition of wage differential in the following matrix form: ${ }^{\mathrm{xvi}}$

$$
\ln W_{C B}-\ln W_{F B}=\bar{X}_{C B}^{T}\left(\hat{\beta}_{C B}-\hat{\beta}_{P}\right)+\bar{X}_{F B}^{T}\left(\hat{\beta}_{P}-\widehat{\beta}_{F B}\right)+\left(\hat{X}_{C B}-\hat{X}_{F B}\right)^{T} \hat{\beta}_{P}
$$

In this decomposition formula, the first term on the right hand side represents the amount by which productive characteristics of the Canadian-born are overvalued 
(positive discrimination), the second term measures the amount of the labour market undervaluation of productive characteristics for naturalized Canadian citizens (negative discrimination), and the third term attributes earnings differences to differences in different productive characteristics (human capital endowments) of the two populations. We conduct this decomposition experiment across genders and source country groups.

Table 6 reports the decomposition results which suggest that, regardless of the region of origin, naturalized male citizens are better endowed with human capital than their native-born counterparts, whereas females are approximately on a par with nativeborn females. ${ }^{\text {xvii }}$ For example, in the absence of (positive) labour market discrimination, naturalized male Canadians would have earned $12.87 \%$ greater wages than native-born males if they came from OECD countries, and 9.18\% more if they came from Asian countries. However, this advantage in human capital endowments is completely offset by the negative labour market treatment for the Asian group (22.62\%), and slightly reinforced by the overvaluation of productive characteristics for the OECD immigrant citizen group (3.66\%). As a result, males from OECD group earn on average $16.8 \%$ greater wages than the native born, contrary to their counterparts from Asia who earn $14.15 \%$ smaller wages than the native-born average.

Table 6: Decomposition of wage differentials between naturalized and native-born Canadians: population of male employees 25-65 years old

\begin{tabular}{|l|l|l|l|l|}
\hline $\begin{array}{l}\text { Source countries } \\
\text { for naturalized } \\
\text { citizens }\end{array}$ & $\begin{array}{l}\text { Native-born }- \\
\text { naturalized } \\
\text { citizens wage } \\
\text { differential }\end{array}$ & $\begin{array}{l}\text { Positive } \\
\text { discrimination } \\
\text { for native- } \\
\text { born }\end{array}$ & $\begin{array}{l}\text { Negative } \\
\text { discrimination } \\
\text { for naturalized } \\
\text { citizens }\end{array}$ & $\begin{array}{l}\text { Human capital } \\
\text { endowments } \\
\text { effect }\end{array}$ \\
\hline All countries & $\mathbf{- 0 . 6 \%}$ & $1.57 \%$ & $7.85 \%$ & $-10.03 \%$ \\
\hline OECD & $\mathbf{- 1 6 . 8 \%}$ & $-0.26 \%$ & $-3.66 \%$ & $-12.87 \%$ \\
\hline NOECD & $\mathbf{1 4 . 1 5 \%}$ & $0.71 \%$ & $22.62 \%$ & $-9.18 \%$ \\
\hline
\end{tabular}

Source: Authors' calculations

Interesting conclusions arise from the decomposition results for females in Table 7. Compared to their native-born counterparts, female workers from Asian countries demonstrate an equal wage earnings performance with no labour market discrimination or human capital disparity. Small positive discrimination (4.78\%) is detected for females 
from OECD countries. This positive discrimination and their slightly greater productive characteristics translate into $8.6 \%$ wage premium over the average native-born female from OECD countries.

Table 7. Decomposition of wage differentials between naturalized and native-born Canadians: population of female employees 25-65 years old

\begin{tabular}{|c|c|c|c|c|}
\hline $\begin{array}{l}\text { Source countries } \\
\text { for naturalized } \\
\text { citizens }\end{array}$ & $\begin{array}{l}\text { Native-born }- \\
\text { naturalized } \\
\text { citizens wage } \\
\text { differential }\end{array}$ & $\begin{array}{l}\text { Positive } \\
\text { discrimination } \\
\text { for native- } \\
\text { born }\end{array}$ & $\begin{array}{l}\text { Negative } \\
\text { discrimination } \\
\text { for naturalized } \\
\text { citizens }\end{array}$ & $\begin{array}{l}\text { Human capital } \\
\text { endowments } \\
\text { effect }\end{array}$ \\
\hline All countries & $\mathbf{- 4 . 1 6 \%}$ & $-0.41 \%$ & $-2.13 \%$ & $-1.62 \%$ \\
\hline OECD & $\mathbf{- 8 . 6 \%}$ & $-0.31 \%$ & $-4.78 \%$ & $-3.5 \%$ \\
\hline NOECD & $\mathbf{1 . 6 9 \%}$ & $0.0 \%$ & $0.26 \%$ & $1.42 \%$ \\
\hline
\end{tabular}

Source: Authors' calculations

In sum, ascension to Canadian citizenship does not equalize the earning potentials of immigrants and native-born. Our analysis indicates that labour market earnings performance of naturalized foreign-born Canadians is conditioned by their country of birth. ${ }^{\text {xviii }}$ We found that, depending on their birth place, male foreign-born citizens experience a greater over- or under-valuation of their productive characteristics than the female foreign-born.

How does the Canadian labour market discriminate between foreign-born workers with and without citizenship? Is the foreign-born citizenship earnings premium reported in Figures 6 and 7, owing to discrimination by citizenship status within the foreign-born group, or due to varying degrees of human capital endowment? If the earnings premium derived from citizenship is due to differential human capital endowments across the foreign-born, we will have established evidence of positive self-selection into citizenship ascension. In other words, better endowed foreign-born immigrants ascend to citizenship. If the earnings premium is owing to overvaluation of foreign-born citizens' productive characteristics, then positive discrimination explains the citizenship wage premium.

To answer these questions, we turn to our decomposition analysis between foreignborn citizens and non-citizens in Table 8.

Table 8. Decomposition of wage differentials between naturalized citizens and permanent residents of Canada: population of foreign-born employees 25-65 years old 


\begin{tabular}{|c|c|c|c|c|}
\hline & \begin{tabular}{ll}
\multicolumn{2}{c}{ Naturalized } \\
citizens \\
permanent \\
residents \\
differential \\
\end{tabular} & $\begin{array}{l}\text { Positive } \\
\text { discrimination } \\
\text { for naturalized } \\
\text { citizens }\end{array}$ & $\begin{array}{l}\text { Negative } \\
\text { discrimination } \\
\text { for permanent } \\
\text { residents }\end{array}$ & $\begin{array}{l}\quad \text { Human } \\
\text { capital } \\
\text { endowments } \\
\text { effect }\end{array}$ \\
\hline & \multicolumn{4}{|c|}{ All occupations } \\
\hline Males & $35.65 \%$ & $1.24 \%$ & $4.37 \%$ & $30.04 \%$ \\
\hline \multirow[t]{2}{*}{ Females } & $34.87 \%$ & $1.85 \%$ & $6.19 \%$ & $26.83 \%$ \\
\hline & \multicolumn{4}{|l|}{ Professionals } \\
\hline Males & $28.51 \%$ & $1.10 \%$ & $4.96 \%$ & $22.45 \%$ \\
\hline Females & $21.86 \%$ & $0.72 \%$ & $3.19 \%$ & $17.94 \%$ \\
\hline
\end{tabular}

Source: Authors' calculations

It is clear that for either males or females in general (all occupations), or for professionals in particular, that the substantial wage differential which arises between foreign-born citizens and non-citizens (column 2) is due predominately to differences in human capital endowments. For example, all foreign-born males earned 35.6\% more as citizens than non-citizens, and differences in human capital endowments explained about $85 \%$ of this wage premium. A similar pattern holds for the foreign-born professionals, suggesting positive self-selection into citizenship acquisition for both professionals and all the foreign-born. It also should be noted from Table 1, which reports the endowments for the various populations, that the most profound difference in endowments reported is number of weeks worked. In short, a greater percentage of naturalized citizens work fulltime $(75 \%)$ than non-citizens $(62 \%)$.

Finally, the decomposition results by entry cohort (Appendix D) clearly indicate that wage earnings differential between citizens and non-citizens is 3-3.5 times (5-6 times in professional occupations) higher for immigrants who landed after 1980. This wage earnings gap is mostly explained by the greater human capital endowments effect in the post 1980 cohort.

\section{Conclusions}

Ascension to citizenship for a select group of Canadian immigrants follows the socio-economic model presented here. Immigrants from poor countries (non-OECD) and immigrants who ascend to citizenship when it is first possible (4-6 years) have their 
decision conditioned by their wage, marital status, age and presence of children. Immigrants from developed OECD countries base their decision primarily on the prospect of an earnings gain from citizenship and years in Canada. This decision-making process holds for both males and females.

The economic impact of this citizenship decision is substantial in the Canadian context. There exists a substantial gap between the immigrants' intended occupation prior to arrival and the actual occupations after entering Canada's labour force. Female immigrants' acquisition of citizenship restored their occupational distribution, which then more closely resembled their intended occupation prior to arrival. This restoration does not occur for foreign-born males.

In addition, after citizenship acquisition, both male and female immigrants experience a rise in earnings. The interaction of citizenship, occupation and language boosts immigrant earnings in managerial, professional and administrative occupations. This suggests that citizenship acts as a signal for language competency, and that it reduces cultural distance.

Our simulation experiments traced the effect of citizenship on foreign-born earnings relative to Canadians over their lifetimes. They indicated that, in the majority of cases, ascension to citizenship reduced the earnings gaps relative to Canadians, and allowed the foreign-born citizens to earn a premium.

Finally, decomposition analysis indicates that the citizenship earnings premium awarded to the Canadian foreign-born is owing to their greater human capital endowment relative to their Canadian-born reference group. In addition, citizens from OECD countries received a premium for these human capital characteristics, while Asian immigrants experienced a devaluation in their credentials. When we decompose the sources of earnings differences between foreign-born citizens and non-citizens, the earnings advantage from citizenship is explained almost entirely by the greater human capital endowment of foreign-born citizens, especially the number of full-time workers. This suggests positive self-selection into citizenship and the need to explore a model which recognizes that number of weeks worked, or earnings and citizenship, may be endogenous. 


\section{ACKNOWLEDGEMENTS}

We would like to acknowledge the financial support of RIIM, Vancouver's Centre of Excellence on Immigration, and the Willy Brandt Guest Professorship at IMER, Malmö University. Comments at the IMER workshops at the Universities of Malmö and Bergen, and IZA, Bonn have improved the original draft. Tommy Bengsston also provided insightful comments.

\section{REFERENCES}

Akbar, S. 1995. Family Reunification. In D. J. DeVoretz (ed.), Diminishing Returns. Vancouver: C.D. Howe Institute Toronto and Laurier Institution, pp. 65-82.

Barkan E.R., and Khokhlov N. 1980. Socioeconomic data as indices of naturalization patterns in the United States: A theory revisited. Ethnicity, 7: 159-190.

Bernard, W.S. 1936. Cultural Determinants of Naturalization, American Sociological Review, 1: 943-953.

Bevelander, P. 2000. Immigrant Employment Integration and Structural Change in Sweden: 1970-1995. Lund Studies in Economic History 15. Lund: Lund University Press.

Bloemraad, I. 2000. Citizenship and Immigration: A Current Review. Journal of International Migration and Integration 1(1): 9-38.

2002. "Who Claims Dual Citizenship? The Limits of Post nationalism, the Possibilities of Transnationalism, and the Persistence of Traditional Citizenship", Department of Sociology, Harvard University. Unpublished manuscript. 
Bratsberg B., J. F. Ragan and Z. M. Nasir. 2002. The effect of naturalization on wage growth: A panel study of young male immigrants. Journal of Labor Economics 20(3): 568-597.

Cotton, J. 1988. On the Decomposition of Wage Differentials. Review of Economics and Statistics 70 (2): 236-243.

DeVoretz, D. J. and C. Iturralde. 2001. Why do the highly skilled stay in Canada?, Policy Options, March, 59-63.

DeVoretz, D. J. and J. Ma. 2002. Triangular Human Capital Flows between Sending, Entrepot and the Rest of the World Regions, Canadian Studies in Population, 29 (1): 53-69.

DeVoretz, D. J. and K. Zhang. Forthcoming 2004. Citizenship, Passports and the Brain Exchange Triangle. Journal of Comparative Policy Analysis.

Kelley, J., and McAllister, I. 1982. The decision to become an Australian citizen. Australian and New Zealand Journal of Sociology, 18(3): 428-439.

Mata, F. 1999. Patterns of Acquiring Citizenship. In S. S. Halli and L. Driedger (eds.), Immigrant Canada: Demographic, Economic and Social Challenges. Toronto: University of Toronto Press, pp. 163-182.

Pendakur, K. and Pendakur, R. 1998. The Colour of Money, Earnings Differentials among Ethnic Groups in Canada. Canadian Journal of Economics 31(3): 518-548.

Pivnenko, S. and D. J. DeVoretz. 2004. The Recent Economic Performance of Ukrainian Immigrants in Canada and the US. RIIM Working Paper 2003. Also published as IZA Working Paper No. 913. 
Portes, A., and Curtis, J.W. 1987. Changing flags: Naturaalization and its determinants among Mexican Immigrants. International Migration Review, 21(2): 352-371.

Portes, A., and R. Mozo 1985. The political adaptation process of Cubans and other ethnic minorities in the United States: A preliminary analysis. International Migration Review, 16(1): 35-63.

Scott, K. 1999. The Immigrant Experience: Changing Employment and Income patterns in Sweden, 1970-1993. Lund Studies in Economic History 9. Lund: Lund University Press.

2004. The Economics of Citizenship. Is there a Naturalization Premium?. Paper presented at the conference Immigrant Ascension to Citizenship: Economic and Social Consequences. June 7, IMER, Malmö University.

Yang, P.Q. 1994. Explaining immigrant naturalization. International Migration Review, 28(3): 449-477. 


\section{APPENDIX A: Working Sample Description and List of Variables}

In this paper we use the data from the 5\% censored sample from 1996 Census of Canada (Public Use Microdata File). The population of interest was restricted to all foreign-born who in 1996 were between 25 and 65 years of age, lived in Quebec, Ontario, Manitoba, Saskatchewan, Alberta or British Columbia, and reported themselves full-time employed as paid workers in 1995. In sum, our working sample of 46,925 immigrants included 36,372 naturalized Canadian citizens and 10,553 non-citizens (permanent residents).

\section{$\underline{\text { Table } 4}$}

Dependent variable: natural logarithm of annual wage earnings LNWAGE

AGEP - age

AGESQ - age squared

LNWKS - natural logarithm of weeks worked

Dummy Variables:

YSM - years since immigration

CTZN - Canadian citizenship indicator (1 for naturalized citizens, 0 - noncitizens)

HLN - indicator for official language (English and/or French) spoken at home

DIPL - indicator for college diploma or trades certificate

$\mathrm{BACH}$ - indicator for bachelor degree

BACHPL - indicator for unfinished schooling above bachelor level, master's degree or medical degree

PHD - indicator for doctoral degree

MAN_CTZ - indicator for citizens in managerial occupations

PROF_CTZ - indicator for citizens in professional occupations

ADM_CTZ - indicator for citizens in administrative and clerical occupations

\section{$\underline{\text { Table } 5}$}

LNWAGE - natural logarithm of wage earnings

AGESQ - age squared 
LNWEEKS - natural logarithm of weeks worked

Dummy variables:

YSM - years since immigration

CTZN - Canadian citizenship indicator

DIPL - indicator for a college diploma or trades certificate

$\mathrm{BACH}$ - indicator for bachelor degree

BACHPL - indicator for unfinished schooling above bachelor level, master's degree or medical degree

PHD - indicator for doctoral degree

HLN_CZN - non-English speaking country of origin interacted with citizenship

HL_CZ_MN - triple interaction of official language spoken at home, Canadian citizenship and managerial occupation

HL_CZ_PR - triple interaction of official language spoken at home, Canadian citizenship and professional occupation

HL_CZ_AD- triple interaction of official language spoken at home, Canadian citizenship and administrative occupation 
Appendix B: Age-Earnings Simulations by country of origin and

\section{Citizenship status}

Figure B-1. Age-earnings profiles for the Canadian Born (CB), Germans Canadian Born (GerCB), German Immigrants Canadian citizens (Gerlm_C) and German Immigrants non-citizens of Canada (GerIm_NC)

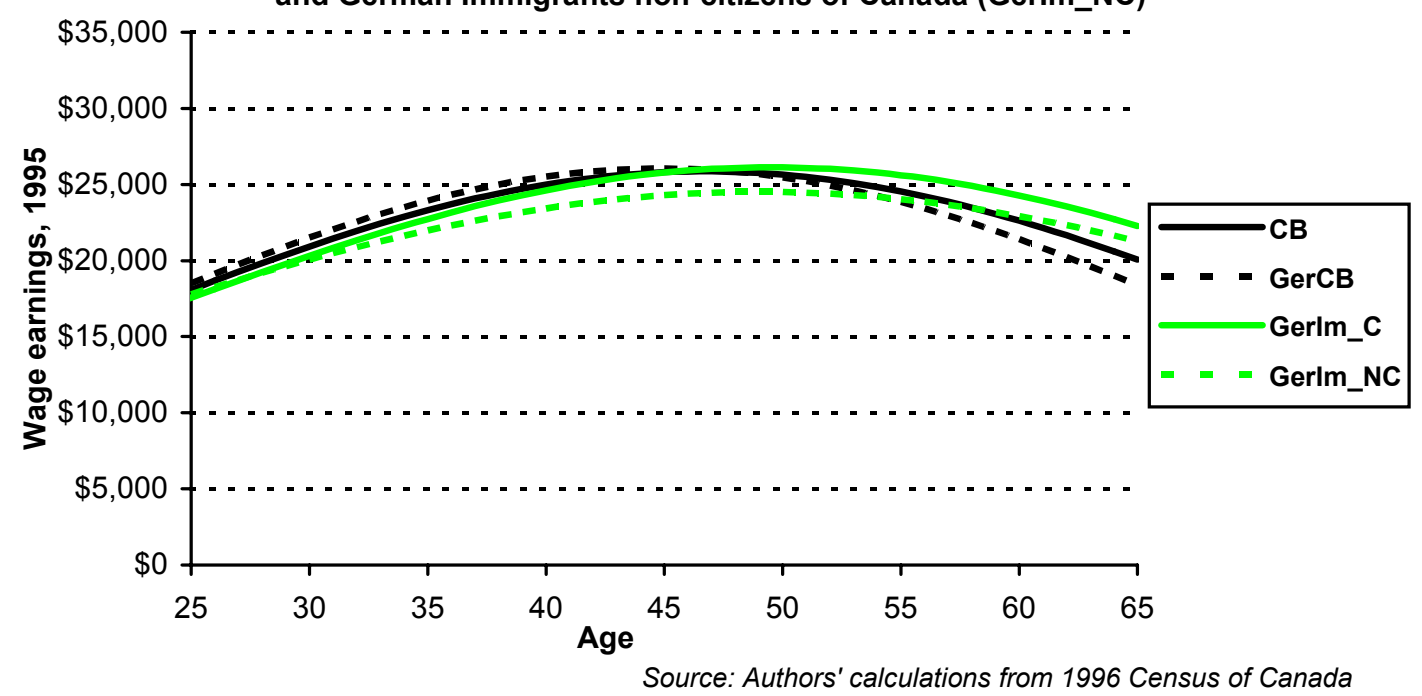


Figure B-2. Age-earnings profiles for the Canadian Born (CB), Italians Canadian Born (ItaCB), Italian Immigrants Canadian citizens (Italm_C) and Italian Immigrants non-citizens of Canada (Italm_NC)

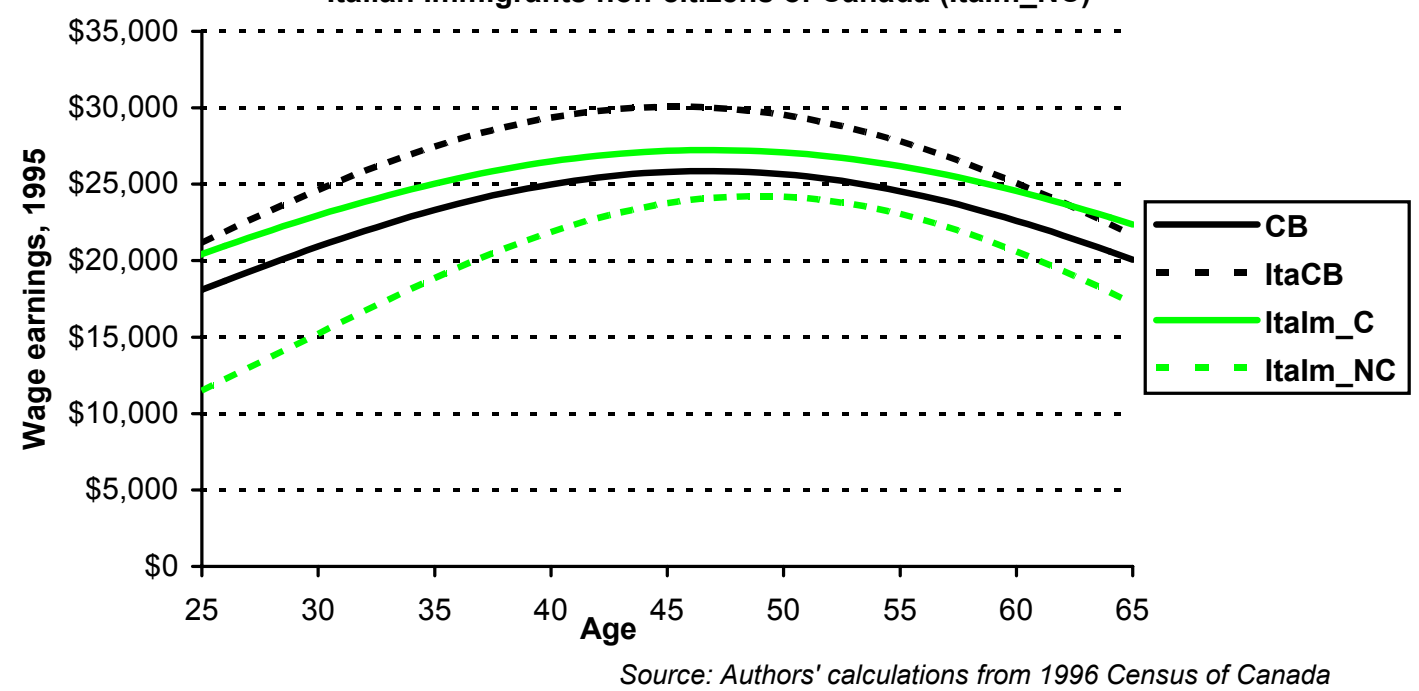

Figure B-3. Age-earnings profiles for the Canadian Born (CB), Ukrainians Canadian Born (UkrCB), Ukrainian Immigrants Canadian citizens (UkrIm_C) and Ukrainian Immigrants non-citizens of Canada (Ukrlm_NC)

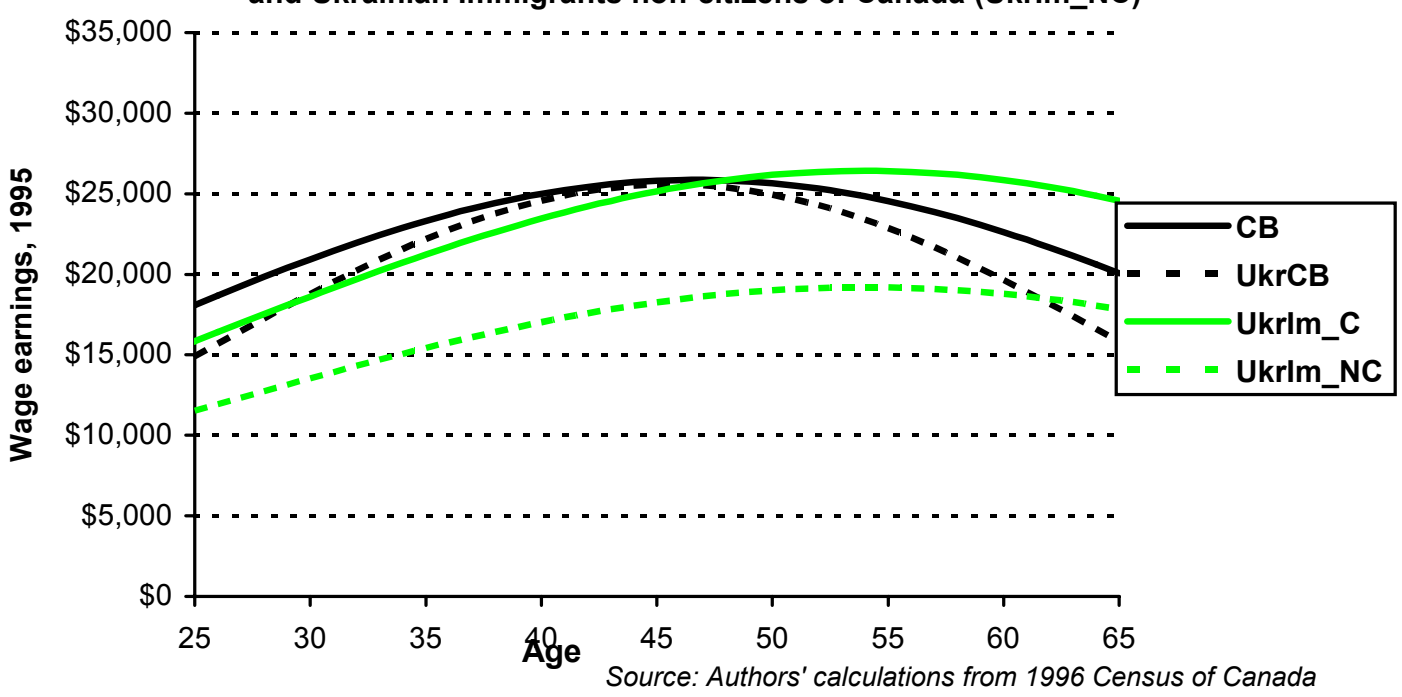




\section{Appendix C: Pre 1981 and Post 1980 Cohort Analysis}

Table C-1: Males and females: pre 1980 cohort

Source: Authors' calculations from 1996 Census of Canada

\begin{tabular}{|c|c|c|c|c|c|c|}
\hline & \multicolumn{3}{|c|}{ Males } & \multicolumn{3}{|c|}{ Females } \\
\hline Variable & Coefficient & b/St.Er. & $\mathrm{P}[|\mathrm{Z}|>\mathrm{Z}]$ & Coefficient & b/St.Er. & $\mathrm{P}[|\mathrm{Z}|>\mathrm{z}]$ \\
\hline Constant & 5.20719 & 55.644 & 0.0000 & 5.990252 & 55.213 & 0.0000 \\
\hline AGE & 0.071604 & 18.617 & 0.0000 & 0.037894 & 8.477 & 0.0000 \\
\hline AGESQ & -0.00069 & -16.27 & 0.0000 & -0.00037 & -7.367 & 0.0000 \\
\hline HLN & 0.165568 & 15.619 & 0.0000 & 0.095996 & 7.943 & 0.0000 \\
\hline DIPL & 0.134785 & 12.75 & 0.0000 & 0.105238 & 8.68 & 0.0000 \\
\hline BACH & 0.266773 & 16.766 & 0.0000 & 0.291546 & 16.964 & 0.0000 \\
\hline BACHPL & 0.382207 & 19.656 & 0.0000 & 0.410319 & 18.145 & 0.0000 \\
\hline PHD & 0.543217 & 17.463 & 0.0000 & 0.68012 & 11.17 & 0.0000 \\
\hline CITIZ & -0.04723 & -3.18 & 0.0015 & -0.14836 & -8.641 & 0.0000 \\
\hline MAN_CTZ & 0.308717 & 19.669 & 0.0000 & 0.434371 & 19.208 & 0.0000 \\
\hline PROF_CTZ & 0.157334 & 11.371 & 0.0000 & 0.422488 & 25.335 & 0.0000 \\
\hline SUPR_CTZ & 0.183518 & 8.511 & 0.0000 & 0.276834 & 8.374 & 0.0000 \\
\hline ADM_CTZ & -0.05083 & -2.676 & 0.0075 & 0.225686 & 16.105 & 0.0000 \\
\hline LNWEEKS & 0.841626 & 69.488 & 0.0000 & 0.782009 & 56.168 & 0.0000 \\
\hline $\begin{array}{l}\text { Adjusted } \\
\text { R-squared } \\
\text { Model test } \\
\text { F[20.26803](prob) }\end{array}$ & \multicolumn{3}{|l|}{0.35026} & \multicolumn{3}{|l|}{0.34397} \\
\hline
\end{tabular}

Table C-2: Males and females: post 1980 cohort

Source: Authors' calculations from 1996 Census of Canada

\begin{tabular}{|c|c|c|c|c|c|c|}
\hline & \multicolumn{3}{|c|}{ Males } & \multicolumn{3}{|c|}{ Females } \\
\hline Variable & Coefficient & b/St.Er. & $\mathrm{P}[|\mathrm{Z}|>\mathrm{z}]$ & Coefficient & b/St.Er. & $\mathrm{P}[|\mathrm{Z}|>\mathrm{z}]$ \\
\hline Constant & 5.143522 & 39.722 & 0.0000 & 5.563532 & 41.056 & 0.0000 \\
\hline AGE & 0.066925 & 11.007 & 0.0000 & 0.048454 & 7.431 & 0.0000 \\
\hline AGESQ & -0.00076 & -10.427 & 0.0000 & -0.00056 & -6.997 & 0.0000 \\
\hline HLN & 0.205126 & 14.514 & 0.0000 & 0.143756 & 9.706 & 0.0000 \\
\hline DIPL & 0.150725 & 9.195 & 0.0000 & 0.12234 & 7.119 & 0.0000 \\
\hline BACH & 0.212626 & 10.114 & 0.0000 & 0.208628 & 9.671 & 0.0000 \\
\hline BACHPL & 0.289934 & 11.57 & 0.0000 & 0.296843 & 10.102 & 0.0000 \\
\hline PHD & 0.456015 & 10.35 & 0.0000 & 0.55444 & 7.453 & 0.0000 \\
\hline CITIZ & 0.060448 & 3.792 & 0.0001 & 0.022753 & 1.278 & 0.2012 \\
\hline MAN_CTZ & 0.28705 & 8.568 & 0.0000 & 0.355633 & 8.056 & 0.0000 \\
\hline PROF_CTZ & 0.275911 & 11.665 & 0.0000 & 0.431866 & 15.981 & 0.0000 \\
\hline SUPR_CTZ & 0.1847 & 4.165 & 0.0000 & 0.2492 & 3.96 & 0.0001 \\
\hline ADM_CTZ & -0.00119 & -0.038 & 0.9699 & 0.25837 & 11.535 & 0.0000 \\
\hline LNWEEKS & 0.856983 & 58.504 & 0.0000 & 0.781598 & 54.809 & 0.0000 \\
\hline Adjusted & \multirow{2}{*}{\multicolumn{3}{|c|}{0.3565}} & \multirow{2}{*}{\multicolumn{3}{|c|}{0.39112}} \\
\hline R-squared & & & & & & \\
\hline $\begin{array}{l}\text { Model test } \\
\text { F[20,26803](prob) }\end{array}$ & \multicolumn{3}{|l|}{$425.29(.0000)$} & \multicolumn{3}{|c|}{$378.51(.0000)$} \\
\hline
\end{tabular}




\section{Appendix D: OAXACA-BINDER Decomposition Results by Cohorts}

Table D-1: Decomposition of wage differentials between naturalized and native-born Canadians: population of male employees 25-65 years old Source: Authors' calculations from 1996 Census of Canada

\begin{tabular}{|c|c|c|c|c|c|}
\hline $\begin{array}{c}\text { Source } \\
\text { countries for } \\
\text { naturalized } \\
\text { citizens }\end{array}$ & Cohorts & $\begin{array}{c}\text { Native-born } \\
\text { - naturalized } \\
\text { citizens wage } \\
\text { differential }\end{array}$ & $\begin{array}{c}\text { Positive } \\
\text { discrimination } \\
\text { for native- } \\
\text { born }\end{array}$ & $\begin{array}{c}\text { Negative } \\
\text { discrimination } \\
\text { for naturalized } \\
\text { citizens }\end{array}$ & $\begin{array}{c}\text { Human } \\
\text { capital } \\
\text { endowments } \\
\text { effect }\end{array}$ \\
\hline OECD & All & $\mathbf{- 1 6 . 8 \%}$ & $-0.26 \%$ & $-3.66 \%$ & $-12.87 \%$ \\
& Pre1981 & $\mathbf{- 1 7 . 5 \%}$ & $-2.04 \%$ & $-0.1 \%$ & $-15.38 \%$ \\
& Post 1980 & $\mathbf{- 1 0 . 6 2 \%}$ & $0.37 \%$ & $-0.49 \%$ & $-10.5 \%$ \\
\hline NOECD & All & $\mathbf{1 4 . 1 5 \%}$ & $0.71 \%$ & $22.62 \%$ & $-9.18 \%$ \\
& Pre1981 & $\mathbf{- 0 . 0 1 \%}$ & $15.9 \%$ & $-0.18 \%$ & -15.78 \\
& Post 1980 & $\mathbf{3 1 . 8 2 \%}$ & $33.8 \%$ & $-0.14 \%$ & $-1.83 \%$ \\
\hline
\end{tabular}

Table D-2: Decomposition of wage differentials between naturalized and native-born Canadians: population of female employees 25-65 years old Source: Authors' calculations from 1996 Census of Canada

\begin{tabular}{|c|c|c|c|c|c|}
\hline $\begin{array}{c}\text { Source } \\
\text { countries for } \\
\text { naturalized } \\
\text { citizens }\end{array}$ & Cohorts & $\begin{array}{c}\text { Native-born } \\
\text { naturalized } \\
\text { citizens } \\
\text { wage } \\
\text { differential }\end{array}$ & $\begin{array}{c}\text { Positive } \\
\text { discrimination } \\
\text { for native- } \\
\text { born }\end{array}$ & $\begin{array}{c}\text { Negative } \\
\text { discrimination } \\
\text { for naturalized } \\
\text { citizens }\end{array}$ & $\begin{array}{c}\text { Human } \\
\text { capital } \\
\text { endowments } \\
\text { effect }\end{array}$ \\
\hline OECD & All & $\mathbf{- 8 . 6 \%}$ & $-0.31 \%$ & $-4.78 \%$ & $-3.5 \%$ \\
& Pre1981 & $\mathbf{- 9 . 9 6 \%}$ & $-7.0 \%$ & $-0.3 \%$ & $-2.66 \%$ \\
& Post 1980 & $\mathbf{1 . 9 8 \%}$ & $5.36 \%$ & $0.65 \%$ & $-4.02 \%$ \\
\hline NOECD & All & $\mathbf{1 . 6 9 \%}$ & $0.0 \%$ & $0.26 \%$ & $1.42 \%$ \\
& Pre1981 & $\mathbf{- 1 5 . 0 8 \%}$ & $-8.54 \%$ & $0.0 \%$ & $-6.53 \%$ \\
& Post 1980 & $\mathbf{1 8 . 8 4 \%}$ & $15.41 \%$ & $0.09 \%$ & $3.34 \%$ \\
\hline
\end{tabular}


Table D-3: Decomposition of wage differentials between naturalized citizens and permanent residents of Canada: population of foreign born employees 25-65 years old Source: Authors' calculations from 1996 Census of Canada

\begin{tabular}{|c|c|c|c|c|c|}
\hline & Cohort & $\begin{array}{c}\text { Naturalized } \\
\text { citizens - } \\
\text { permanent } \\
\text { residents wage } \\
\text { differential }\end{array}$ & $\begin{array}{c}\text { Positive } \\
\text { discrimination } \\
\text { for naturalized } \\
\text { citizens }\end{array}$ & $\begin{array}{l}\text { Negative } \\
\text { discrimination } \\
\text { for permanent } \\
\text { residents }\end{array}$ & $\begin{array}{c}\text { Human } \\
\text { capital } \\
\text { endowments } \\
\text { effect }\end{array}$ \\
\hline & & \multicolumn{4}{|c|}{ All occupations } \\
\hline Males & $\begin{array}{r}\text { All } \\
\text { Pre1981 } \\
\text { Post } 1980\end{array}$ & $\begin{array}{c}35.65 \% \\
9.00 \% \\
28.90 \%\end{array}$ & $\begin{array}{l}1.24 \% \\
0.24 \% \\
5.47 \%\end{array}$ & $\begin{array}{l}4.37 \% \\
1.79 \% \\
8.31 \%\end{array}$ & $\begin{array}{c}30.04 \% \\
6.97 \% \\
15.12 \%\end{array}$ \\
\hline Females & $\begin{array}{r}\text { All } \\
\text { Pre1981 } \\
\text { Post 1980 }\end{array}$ & $\begin{array}{c}34.87 \% \\
9.40 \% \\
32.27 \% \\
\end{array}$ & $\begin{array}{l}1.85 \% \\
0.61 \% \\
5.86 \%\end{array}$ & $\begin{array}{l}6.19 \% \\
4.16 \% \\
9.02 \%\end{array}$ & $\begin{array}{c}26.83 \% \\
4.62 \% \\
17.39 \%\end{array}$ \\
\hline & & \multicolumn{4}{|c|}{ Professionals } \\
\hline Males & $\begin{array}{r}\text { All } \\
\text { Pre1981 } \\
\text { Post } 1980\end{array}$ & $\begin{array}{c}28.51 \% \\
4.86 \% \\
25.61 \%\end{array}$ & $\begin{array}{l}1.10 \% \\
0.16 \% \\
4.90 \%\end{array}$ & $\begin{array}{l}4.96 \% \\
1.65 \% \\
8.90 \%\end{array}$ & $\begin{array}{c}22.45 \% \\
3.05 \% \\
11.81 \%\end{array}$ \\
\hline Females & $\begin{array}{r}\text { All } \\
\text { Pre1981 } \\
\text { Post } 1980\end{array}$ & $\begin{array}{c}21.86 \% \\
3.01 \% \\
22.01 \%\end{array}$ & $\begin{array}{l}0.72 \% \\
0.22 \% \\
3.45 \%\end{array}$ & $\begin{array}{l}3.19 \% \\
1.67 \% \\
6.62 \%\end{array}$ & $\begin{array}{c}17.94 \% \\
1.12 \% \\
11.95 \%\end{array}$ \\
\hline
\end{tabular}




\section{ENDNOTES}

${ }^{i}$ The Census of Canada does not provide any information on the year of citizenship acquisition.

ii The Court argued in the majority that, since there was no barrier to becoming a Canadian citizen, then inherently immigrants did not face discrimination, but just a waiting period which applied to all immigrants.

iii Of course, there are many non-economic objections to returning immigrants, including an alleged lack of patriotism or failure to integrate into the Canadian economy.

${ }^{\text {iv }}$ Concerns over the brain drain are redoubled if emigrating Canadian citizens obtained their schooling in Canada.

v The interesting exceptions were immigrants from Denmark, Finland, Greece and the USA, who experienced no citizenship effect on their employment probabilities in Sweden.

${ }^{\text {vi }}$ One apparent strategy for Chinese immigrants is for one of the two spouses to ascend to Canadian citizenship, while the other spouse remains Chinese. This insures access to China for the spouse who is not a Canadian citizen.

vii These countries include China, France, Germany, India, Italy, Lebanon, Netherlands, Philippines, Poland, Portugal, United Kingdom, United States, Vietnam, and Yugoslavia, for a total of 23,715 observations.

viii Our target population includes male and female immigrants 25-65 years old, who reported wage income in 1995.

${ }^{\text {ix }}$ For non-citizens this variable is calculated as $L N W D I F_{i}=\hat{\beta}_{C} X_{i}-L N W A G E_{i}$, for citizens $L N W D I F_{i}=L N W A G E_{i}-\hat{\beta}_{N C} X_{i}$; where LNWAGEi - logarithm of individual's annual wage earnings, $X \mathrm{i}-$ vector of individual's characteristics, $\hat{\beta}_{N C}$ and $\hat{\beta}_{C}$ are vectors of OLS coefficients estimated from log-linear earnings equations for non-citizens and citizens respectively

This variable equals the mean income difference between a 35-year old immigrant with Canadian citizenship and without, from the particular country of origin, for the sampled observation. Figures 7 and 8 illustrate how this was computed.

${ }^{x}$ The OECD countries include France, Germany, Italy, Netherlands, Spain, Greece, Portugal, United Kingdom, and United States.

${ }^{x i}$ Note that the dual variable was found incorrectly signed in the process of model testing and dropped from further analysis. We believe that by increasing our sample size $(20 \%)$, the results will improve as they did for Bloemraad (2002). In the currently available $5 \%$ 
censored sample, most of the immigrant source countries are grouped, which limits the identified non-OECD countries to China, India, Lebanon, Philippines, Poland, Vietnam, former USSR (European) and Yugoslavia.

xii See Bevelander (2000) and Scott (1999) who argue that cultural distance causes segmentation in the Swedish labour market.

xiii In fact, the time period between the declaration of intended occupation and the observed occupation before and after citizenship can be long, and many intervening variables could negate our prediction. For example, selected out-migration or disappearance from the Canadian labour market could have occurred. This would leave us potentially with a less-skilled male foreign-born population, if only skilled Canadian immigrants leave over time, as suggested by DeVoretz and Ma (2002).

xiv Under the 1951 Immigration Act, 75\% of Canada's immigrants entered from Western Europe and the United States in 1967. In 1981, under the 1978 Immigration Act $25 \%$ entered from these countries.

${ }^{x v}$ Under all these simulations the mean values of the relevant variables, except age, are taken from the relevant estimating equation. These equations are available upon request.

xvi This modification of the original Binder-Oaxaca decomposition method was suggested by Cotton (1988).

${ }^{x v i i}$ Because we had to pool natives and immigrants, and because we had to subtract vectors of their regression coefficients, we had to omit the language variable. Its effect was partially captured in the intercept for the foreign-born. Nevertheless, the estimates will be biased.

xviii This confirms the findings of Pendakur and Pendakur (1998). 